\title{
Recent Advances in
} \section{Tungsten-Oxide-Based Materials and Their Applications}

\author{
Chang-Mou Wu*, Saba Naseem, Min-Hui Chou, Jyun-Hong Wang and Ying-Qi Jian \\ Department of Materials Science and Engineering, National Taiwan University of Science and Technology, Taipei, Taiwan
}

Among several active photothermal nanomaterials, tungsten-oxide-based materials have received considerable attention recently because of their ability to absorb near-infrared (NIR) light and their efficient light-to-heat conversion properties. In addition, tungsten-oxide-based materials have an unusual oxygen defect structure and strong local surface plasma resonance (LSPR), which offers strong photoabsorption in a broad wavelength range of the NIR region. In the past, several light-absorbing nanomaterials such as noble metals, polymeric materials, and other inorganic nanomaterials were of interest for their use in photothermal therapy for cancer treatment. In this study, we review the synthesis, properties, and applications of tungsten-oxide-based nanomaterials as a new type of photothermal material. The basic ideas behind photothermal nanomaterial development as well as the factors that influence their structural designs are also discussed in this study. In addition, recent progress in various fields such as NIR light-shielding, pyroelectric, water evaporation, photocatalysis, gas sensors, and energy-related applications for $\mathrm{WO}_{3-\mathrm{x}}$ - and $\mathrm{M}_{\mathrm{x}} \mathrm{WO}_{3}$-based nanomaterials (including their hybrids) are highlighted. Finally, this review presents promising insights into this rapidly growing field that may inspire additional research leading to practical applications.

Donghua University, China Mukul Pradhan, National Institute of Technology

Meghalaya, India

*Correspondence:

Chang-Mou Wu

cmwu@mail.ntust.edu.tw

Specialty section: This article was submitted to

Functional Ceramics,

a section of the journal

Frontiers in Materials

Received: 03 January 2019 Accepted: 04 March 2019 Published: 27 March 2019

Citation:

Wu C-M, Naseem S, Chou M-H, Wang J-H and Jian Y-Q (2019) Recent

Advances in Tungsten-Oxide-Based

Materials and Their Applications.

Front. Mater. 6:49.

doi: 10.3389/fmats.2019.00049

Keywords: photothermal conversion, non-stoichiometric tungsten-oxides $\left(\mathrm{WO}_{2.72}\right)$, tungsten bronze $\left(\mathrm{M}_{\mathbf{x}} \mathrm{WO}_{3}\right)$, water evaporation, photocatalyst

\section{INTRODUCTION}

Near-infrared (NIR) irradiation has a broad wavelength in the range of $780-2,500 \mathrm{~nm}$. Fundamentally, nearly half of the energy available on the earth's surface is composed of sunlight that is near-infrared (i.e., greater than $780 \mathrm{~nm}$ ). Maximizing NIR light for human use has been an interesting topic for scientists. NIR-absorbing photothermal materials (PTMs) have gained research interest because of their attractive light-to-heat behavior. Photothermal conversion is a process in which light energy of a specific wavelength is absorbed and is converted directly into heat. Through light-to-heat conversion, the heat generated can be applied to many fields such as photothermal therapy (Wang et al., 2017a), water evaporation (Wang, 2018), photocatalysis (Wang et al., 2017c), electrochromic devices (Liao et al., 2007), NIR shielding (Li et al., 2016b), and energy-related applications (Liu et al., 2018). PTMs have been used for photothermal ablation (PTA) therapy for the past few decades. Photothermal therapy is used in cancer treatment in which the target tissues are exposed to higher temperatures derived from photothermal properties to destroy abnormal cells (Chen et al., 2013). Yang et al. (2010) studied the in-vivo behavior of PEGylated nanographene sheets in tumor-bearing mice by in-vivo fluorescence imaging and determined that PEGylated nanographene sheets were extremely effective in in-vivo photothermal therapy (PTT). 
In recent years, a variety of nanomaterials, noble metal nanomaterials, carbon-based materials, conductive polymers, and semiconductor nanoparticles have been studied for their NIR absorption properties (Lee et al., 2003; Marques, 2013; Zhang et al., 2015a; Wang et al., 2016a,b, 2017b; Riley and Day, 2017; Chen et al., 2018; Xu et al., 2018; Zhenzhen et al., 2018; Zeng et al., 2019).

Non-stoichiometric metal oxides such as $\mathrm{WO}_{3-\mathrm{x}}, \mathrm{MoO}_{3-\mathrm{x}}$, $\mathrm{CuS}$, and $\mathrm{TiO}_{\mathrm{x}}$ are of particular interest, as their strong photoabsorption properties in the broad wavelength range of the NIR region make them suitable for various applications (Guo et al., 2011b; Chen et al., 2013; Hu et al., 2016; Yan et al., 2016; Ding et al., 2017). In semiconductor-based materials, light is absorbed to generate electron-hole pairs. In particular, tungsten-oxide-based materials are effective in their utilization of the NIR region. Of these, oxygen-deficient $\mathrm{WO}_{2.72}$ have been found to be useful in various applications such as smart windows, electrochromic devices, photothermal therapy, and NIR shielding. Other than photoabsorption properties, $\mathrm{WO}_{\mathrm{x}^{-}}$ based materials with large band gaps have attracted a lot of research interest due to their potential uses in optical recording devices (Aoki et al., 2005), field-emission applications (Baek and Yong, 2007) and high- $\mathrm{T}_{\mathrm{c}}$ superconductors (Reich et al., 2009). Moreover, tungsten-bronze-type compounds with the general structure of $\mathrm{M}_{\mathrm{x}} \mathrm{WO}_{3}\left(\mathrm{M}_{\mathrm{x}} \mathrm{W}_{1-\mathrm{x}}^{+6} \mathrm{~W}_{\mathrm{x}}^{+5} \mathrm{O}_{3}\right.$, where $\mathrm{M}=\mathrm{Cs}, \mathrm{Rb}$, $\mathrm{K}, \mathrm{Na}$, and $\mathrm{NH}_{4}$ ) were developed by doping an element that produces a tungsten bronze structure, which in turn exhibits broadband NIR absorption properties (Kim et al., 2012; Li et al., 2016c). The aim of this review is to discuss $\mathrm{WO}_{2.72}, \mathrm{M}_{\mathrm{X}} \mathrm{WO}_{3}$, and their hybrid-based materials to promote further scientific investigations in this field. The utilization and preparation of common PTMs such as $\mathrm{WO}_{2.72}$ and $\mathrm{M}_{\mathrm{x}} \mathrm{WO}_{3}$ are reported and the preparation techniques, photothermal conversion properties, and recent progress in their applications, including those in NIR shielding, water evaporation, pyroelectricity, photocatalysis, energy-related devices, and gas sensors are highlighted.

\section{PHOTOTHERMAL CONVERSION MATERIALS AND THEIR PROPERTIES}

The first and foremost requirement of a PTM is that it must have a light-absorption capability. During the last few decades, various PTMs with strong light absorbance have been investigated for wide solar spectra. In the literature, various photothermal nanomaterials have been examined. Because of their NIR responsive properties, the photothermal conversion dynamics of these materials have not been fully explored.

Noble-based metals like $\mathrm{Au}, \mathrm{Ag}$, and Pd have been widely studied mainly for applications in cancer therapy. Among them, $\mathrm{Au}$ has been investigated for cancer therapy because of its chemical stability, facile synthesis, high quality, high yield, and nontoxicity (Huang and El-Sayed, 2010). The local surface plasma resonance (LSPR) band is much stronger, particularly for noble metals like Au and Ag. Chen et al. (2007) designed a relatively small gold nanocage with an 810-nm dimension using laser-driven PTT. They showed that immuno-gold nanocages strongly absorb at their LSPR peak and thus might be a major factor in reducing the thermal damage threshold. Despite the advantages related to the photothermal effects of noble metals, their relatively high cost and poor photostability at a prolonged laser irradiation have led the research community to explore other alternatives.

Carbon-based nanomaterials are primarily of two types: graphene- and carbon-nanotube (CNT)-based. These have been used in cancer therapy, solar evaporation, and sensor applications (Hashishin and Tamaki, 2008; Lou et al., 2016; Son et al., 2016; Hu et al., 2017). CNTs are best known for their photothermal conversion properties as well as their low cost, light weight, and high stability. Wang et al. (2016b) studied photothermal CNT-based materials and reported a solar thermal conversion efficiency of as high as $82 \%$ with bilayered CNT-silica materials. Polymers such as polydopamine was pioneered as a biodegradable PTM (Jiang et al., 2017). Organic polymers such as polypyrrole (Zhang et al., 2015a), polyaniline (PANI) (Huang et al., 2015a), and poly(1,3,5hexahydro-1,3,5-triazine) (Chen et al., 2018) have been explored for their photothermal properties. Song et al. (2018) reported that hydrophobic $\mathrm{Cu}_{12} \mathrm{Sb}_{4} \mathrm{~S}_{13}$ nanoparticles deposited on a porous cellulose acetate membrane form a photothermal film that could achieve photothermal heating for vapor generation and antibacterial activity simultaneously under light irradiation.

The research on semiconductor materials is rapidly expanding. In addition, studies are being conducted on noble and carbon-based PTMs, which includes copper chalcogenides, $\mathrm{Ti}_{2} \mathrm{O}_{3}$, MXene- $\left(\mathrm{Ti}_{3} \mathrm{C}_{2}\right), \mathrm{MoO}_{3-\mathrm{x}}$, and $\mathrm{WO}_{3-\mathrm{x}}$ (Guo et al., 2012b; Ding et al., 2017; Lin et al., 2017; Wang et al., 2017b; Yan et al., 2017). These semiconductor-based materials are considered to be highly promising candidates, as they offer desirable photothermal conversion efficiencies. Copper chalcogenides are plasmonic-based metal-oxide-type semiconductors that are promising. Some researchers have investigated copper compounds, as they satisfy the efficiency requirement of strong vis-NIR absorption. Tian et al. (2011) synthesized hydrophilic flower-like CuS by using the hydrothermal method and achieved an enhanced absorption ability for a 980-nm laser. Similarly, nanocomposites like $\mathrm{Cu}_{9} \mathrm{~S}_{5} @ \mathrm{SiO}_{2}$ (Song et al., 2013), $\mathrm{Cu}_{7} \mathrm{~S}_{4}$ (Song et al., 2014), and CuS (Zhou et al., 2010) nanoparticle have been investigated for potential use in 980-nm laser-driven PTA therapy (Hua et al., 2017). developed porous floating HCuPO-PDMS that exhibited a very high absorption in the vis-NIR band at $808 \mathrm{~nm}$. A photothermal conversion effciency of $41.8 \%$ was achieved for solar evaporation by $\mathrm{HCuPO}$ due to $\mathrm{d}-\mathrm{d}$ transition of $\mathrm{Cu}^{2+}$.

In this review, tungsten oxide materials are discussed in more detail with information on preparation and applications of $\mathrm{WO}_{2.72}$ and $\mathrm{M}_{\mathrm{x}} \mathrm{WO}_{3}$. $\mathrm{WO}_{3}$ consists of perovskite units and is one of the most attractive candidates for photothermal conversion because of its suitable band gap $(2.62 \mathrm{eV}$ ) (Huang et al., 2015b). It is also known for its good optical absorption characteristics under ultraviolet light. However, its photothermal conversion ability in NIR is inferior to that of $\mathrm{WO}_{2.72}$. As the NIR absorbent properties of $\mathrm{WO}_{2.72}$ have recently received greater attention, the photothermal performance of $\mathrm{WO}_{3}$ in 
other optical regions has also been investigated. The nonstoichiometric properties of $\mathrm{WO}_{2.72}$ have been an interesting topic over the past decades. Many forms of $\mathrm{WO}_{3-\mathrm{x}}$ such as $\mathrm{WO}_{2.9}, \mathrm{WO}_{2.83}$, and $\mathrm{WO}_{2.72}$, which generally are blue in color, have also been considered because of their unusual defects; these defects improve the electrical conductivity by a large degree. However, these materials are not soluble in any solvent. With a prolonged time, they can be oxidized to $\mathrm{WO}_{3}$. Moreover, the low crystallinity of $\mathrm{WO}_{2.72}$ may be a concern (Sun et al., 2018). Thus far, the photothermal capabilities of other forms of $\mathrm{WO}_{3-\mathrm{x}}$ are still unknown. Doping an element in $\mathrm{WO}_{3}$ produces $\mathrm{M}_{\mathrm{x}} \mathrm{WO}_{3}$, which further enhances the optical absorption in the solar spectrum. $\mathrm{M}_{\mathrm{X}} \mathrm{WO}_{3}$ has also attracted considerable attention because it offers a wide variety of crystal structures and has many interesting attributes such as electrochromic, optical-electrical, and superconductive properties.

Semiconductors such as $\mathrm{WO}_{3-\mathrm{x}}$ are interesting candidates as LSPR hosts because of their unique characteristic of having an outer d-valence electron. $\mathrm{WO}_{3-\mathrm{x}}$ is well-known for its nonstoichiometric properties derived from the presence of numerous oxygen vacancies that can narrow the band gap. The new discrete energy bands below the conduction band are created by the oxygen vacancies (Yan et al., 2015; Zheng et al., 2015). The strong NIR absorption properties are induced by LSPR with an intensity comparable to the bandgap absorption and is achieved either by creating oxygen vacancies or by inserting metal ions. The LSPR band in plasmonic nanoparticles is proportional to the square root of the free electron density in the particle. The LSPR is dependent on certain factors such as the particle size, shape, structure, and the dielectric properties of the metal (Huang and El-Sayed, 2008). $\mathrm{WO}_{3-\mathrm{x}}$ with a band gap of 2.4-3.0 eV are recognized as n-type semiconductors. Heat treatment in a reducing atmosphere is an effective approach to increase the concentration of oxygen vacancies. The dopants contribute electrons and increase the free-electron density in the conduction band. Finally, the LSPR creates an intensive local electric field, which is favorable for many practical applications (a topic to be discussed in the next section). The presence of mixed valence $\mathrm{W}^{5+}$ and $\mathrm{W}^{6+}$ sites are promising for harvesting NIR light through small polaron absorption and for increasing the electrical conductivity (Wang et al., 2017c). Among the non-stoichiometry tungsten oxides, monoclinic $\mathrm{WO}_{2.72}$ (expressed as $\mathrm{W}_{18} \mathrm{O}_{49}$ ) has received considerable interest due to its distinctive oxygen defect structure and intense nearinfrared photoabsorption.

In our previous study, we demonstrated the photothermal conversion properties of $\mathrm{WO}_{2.72}$ /polyurethane (PU) nanocomposites using a UV-Vis NIR spectrometer (Chala et al., 2017). The transmittance values of $\mathrm{WO}_{2.72} / \mathrm{PU}$ were found to be $75 \%$ in the visible region $(400-780 \mathrm{~nm})$. Transmittance of the $\mathrm{WO}_{2.72} / \mathrm{PU}$ nanocomposites in the range of $780-2500 \mathrm{~nm}$ was very low (8\%), which suggested that the $\mathrm{WO}_{2.72} / \mathrm{PU}$ nanocomposites exhibited stronger NIR absorption (92\%) compared to other nanocomposites. This was because of the presence of free electrons or oxygen-vacancy-induced small polarons formed during the reduction process. For comparison, the transmittance spectra of $\mathrm{WO}_{2.8} / \mathrm{PU}, \mathrm{WO}_{3} / \mathrm{PU}$, and $\mathrm{WO}_{2} / \mathrm{PU}$ nanocomposites are also shown (Figure 1A). The $\mathrm{WO}_{3-\mathrm{x}}$ phase went through phase transformations during reduction, under a $\mathrm{CO}$ atmosphere, and created oxygen vacancies that led to a non-stoichiometric structure. The color of the $\mathrm{WO}_{3-\mathrm{x}}$ powder varied after reduction at different temperatures (Figure 1B). The color changed from yellow to dark blue and to black for $\mathrm{WO}_{3}, \mathrm{WO}_{3-\mathrm{x}}$, and $\mathrm{WC}$, respectively. The temperature $\Delta \mathrm{T}$ rapidly increased for $\mathrm{WO}_{2.72} / \mathrm{PU}, \mathrm{WO}_{2.8} / \mathrm{PU}, \mathrm{WO}_{3} / \mathrm{PU}$, and pure $\mathrm{PU}$ to $58.9,41.9,30.9$, and $9.9^{\circ} \mathrm{C}$ after $30 \mathrm{~s}$, respectively (see Figure 1C) (Chala et al., 2017). These results suggested that the $\mathrm{WO}_{2.72} / \mathrm{PU}$ nanocomposites exhibit a faster photothermal conversion rate than do $\mathrm{WO}_{2.8} / \mathrm{PU}, \mathrm{WO}_{3} / \mathrm{PU}$, and pure $\mathrm{PU}$. As previously discussed, $\mathrm{WO}_{2.72}$ considerable instabilities is the result if a longer time passes in which $\mathrm{WO}_{2.72}$ can be oxidized to $\mathrm{WO}_{3}$. This problem can be overcome by $\mathrm{M}_{\mathrm{x}} \mathrm{WO}_{3}$, as it has similar absorption properties. Chen and Chen (2013) reported the photothermal conversion property of $\mathrm{Cs}_{0.33} \mathrm{WO}_{3}$, which exhibited strong characteristic absorption in the NIR region because of free electrons or polarons. It was demonstrated that NIR absorption was considerably enhanced by reducing the particle size or by increasing the particle concentration. In addition, the study reported that it generated a photothermal conversion efficiency of approximately $73 \%$ while demonstrating excellent photothermal stability. An effective NIR absorption and photothermal conversion ability was proved, which revealed great potential for practical applications.

\section{PREPARATION OF TUNGSTEN-OXIDE-BASED MATERIALS}

In this section, we discuss various preparation methods and the pros and cons of synthesizing nanomaterials including $\mathrm{M}_{\mathrm{x}} \mathrm{WO}_{3}$ and $\mathrm{WO}_{3-\mathrm{x}}$. For $\mathrm{M}_{\mathrm{x}} \mathrm{WO}_{3}$, these are summarized in Table 1. These include mechanochemical, vapor-phase synthesis, solid phase reaction, inductively coupled thermal plasma, and hydrothermal and solvothermal methods. Hydrothermal and solvothermal methods have been widely adopted because of their easy scalability.

\section{Mechanochemical Method}

Mechanochemical techniques like ball-milling or grinding are considered to be candidates for solvent-free synthesis. This method involves a chemical transformation which is induced by mechanical energies such as compression, shearing, or friction. Wang et al. (2003) prepared $\mathrm{Na}_{0.88} \mathrm{WO}_{3}$ nanocrystals by grinding the precursor $\mathrm{Na}$ pieces and $\mathrm{WO}_{3}$ powders having an average grain size of $17 \mathrm{~nm}$. Electrical property tests showed that $\mathrm{Na}_{0.88} \mathrm{WO}_{3}$ exhibited semiconductor characteristics that might cause lattice distortion of the material as a result of high-energy ball-milling affecting its electrical conductivity. This process has many advantages including the use of low-cost raw materials, simplicity of process, and the ability to obtain fine particles. However, the main limitation is that the chemical reaction must be controlled for air- and moisture-sensitive substances. 
A

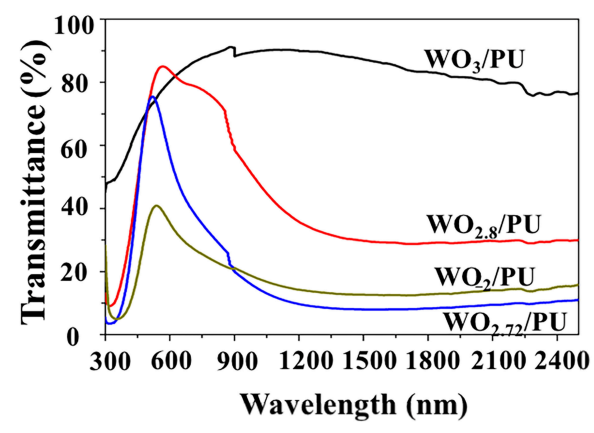

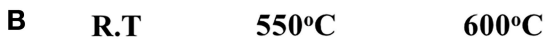

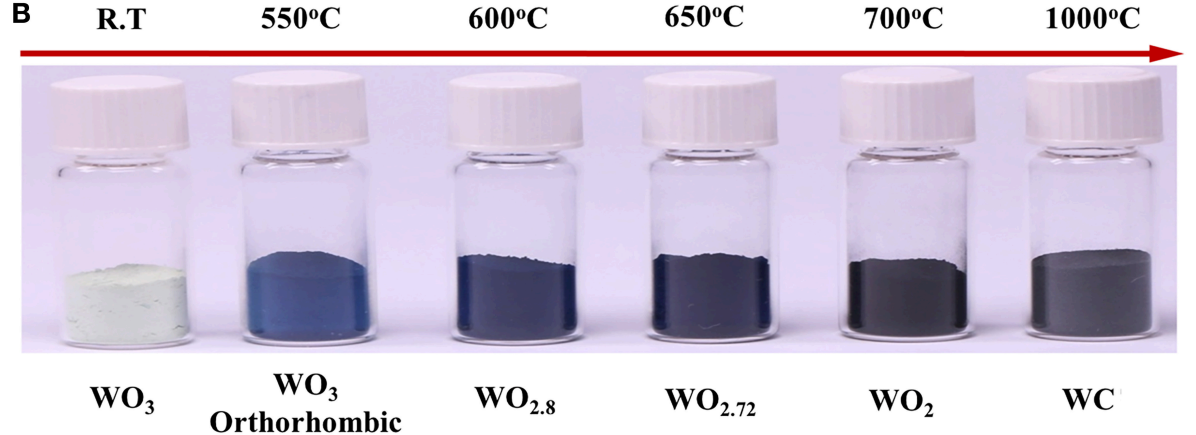

C

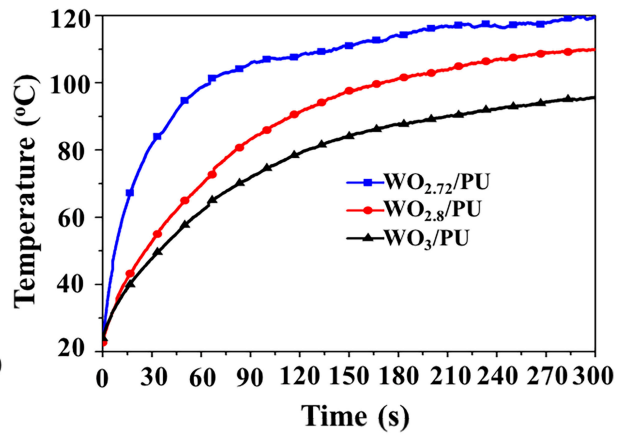

$\mathrm{WO}_{2}$

WC

FIGURE 1 | Photothermalconversion properties of $\mathrm{WO}_{2.72} / \mathrm{PU}$ nanocomposites by (A) UV-Vis-NIR transmittance spectra, (B) variation in the color observed for reduced tungsten oxide powder, and (C) the temperature difference $\mathrm{WO}_{3} / \mathrm{PU}, \mathrm{WO}_{2.8} / \mathrm{PU}$, and $\mathrm{WO}_{2.72} / \mathrm{PU}$ with 7 wt \% as a function of time under infrared light irradiation. Reproduced with permission (Chala et al., 2017). Copyright 2017, MDPI.

\section{Chemical Vapor Transport}

Based on the principles of chemical vapor transport (CVT), volatilization of a solid in the presence of a gaseous reactant (the so-called "transport agent") deposits the solid elsewhere and usually in crystalline form Schmidt et al. (2013). Hussain et al. (1997) employed this method and prepared crystal growth of alkali metal tungsten bronzes $\mathrm{M}_{\mathrm{X}} \mathrm{WO}_{3-\mathrm{x}}(\mathrm{M}=\mathrm{K}, \mathrm{Rb}, \mathrm{Cs})$. Several transport agents were used $\left(\mathrm{HgCl}_{2}, \mathrm{HgBr}_{2}, \mathrm{Hgl}_{2}, \mathrm{Cl}_{2}, \mathrm{PtCl}_{2}\right)$, but $\mathrm{HgCl}_{2}$ and $\mathrm{HgBr}_{2}$ were found to be equally efficient as transport agents for growing large crystals of tungsten bronzes. The crystals were grown to $6 \mathrm{~mm}$ in length for hexagonal tungsten bronzes. However, the tetragonal tungsten bronzes $\left(\mathrm{M}_{\mathrm{x}} \mathrm{WO}_{3}\right)$ were prepared at a size of $0.1 \mathrm{~mm}$ by using $\mathrm{HgCl}_{2}$ and $\mathrm{HgBr}_{2}$, where $\mathrm{x}$ was 0.25 . Yet, when $\mathrm{x} \geq 0.35$, very little or no transport occurred. The transport rate and crystal size were reduced with increasing alkali metal concentration. These were prepared under isothermal conditions both with and without adding transport agents, which showed nearly identical results. However, the results showed an appreciable transport effect when used as transport agents. Note also that the use of transport agents may cause environmental damage with high-energy consumption.

\section{Solid-Phase Reaction}

A solid-phase reaction refers to a process in which a solid reaction occurs between two solids, and a solid product is formed without chemical equilibrium. This technique is simple and requires low-cost equipment. However, it has a slow reaction rate at a high temperature. Preparation of tungsten bronze $\mathrm{Cs}, \mathrm{Rb}, \mathrm{Na}$, and $\mathrm{K}$ have been reported when using the solid-phase reaction method (Lee et al., 2014b). Takeda and Adachi (2007) synthesized hexagonal tungsten bronze (HTB) $\mathrm{Cs}_{0.33} \mathrm{WO}_{3}, \mathrm{Rb}_{0.33} \mathrm{WO}_{3}$ powder and cubic tungsten bronze (CTB) $\mathrm{Na}_{0.75} \mathrm{WO}_{3}$ powder using metal salts mixed with $\mathrm{WO}_{3} \cdot \mathrm{NH}_{3}$ as a precursor that reacted at $550^{\circ} \mathrm{C}$ for $1 \mathrm{~h}$ with $\mathrm{H}_{2} / \mathrm{N}_{2}$ or $\mathrm{H}_{2} / \mathrm{Ar}$. It was then annealed at $800{ }^{\circ} \mathrm{C}$ in an $\mathrm{N}_{2}$ atmosphere for $1 \mathrm{~h}$. $\mathrm{Cs}_{0.33} \mathrm{WO}_{3}$, $\mathrm{Rb}_{0.33} \mathrm{WO}_{3}$ resulted in strong and broad NIR absorption peaking at approximately $1,500 \mathrm{~nm}$. It was revealed that the HTB phase $\mathrm{M}_{0.33} \mathrm{WO}_{3}$ was quite suitable for solar filter applications because of its strong absorption in the NIR range. Moon et al. (2013) demonstrated that quaternary tungsten bronze has better NIR absorption properties in the range of 780 to 1,200 than does tungsten bronze because of the modulated optical response by the quaternary element of sodium.

\section{Inductively Coupled Thermal Plasma Method}

Thermal plasma is mainly used as a heat source for the evaporation of solid precursors or decomposition of gaseous precursors. Reactive gases are used as main constituents to form a plasma flame for synthesis of nano-sized materials. Thermal plasma synthesis of $\mathrm{M}_{\mathrm{x}} \mathrm{WO}_{3}$ was reported by Mamak et al. (2010) in which a powder mixture containing a precursor of $\left(\mathrm{NH}_{4}\right)_{10}\left(\mathrm{H}_{2} \mathrm{~W}_{12} \mathrm{O}_{42}\right) .4 \mathrm{H}_{2} \mathrm{O}$ and salt of HCOOCs, Na2CO3, 
TABLE 1 | List of the preparation methods for tungsten bronze $\left(\mathrm{M}_{\mathbf{x}} \mathrm{WO}_{3}\right)$.

\begin{tabular}{|c|c|c|c|c|}
\hline $\begin{array}{l}\text { Preparation } \\
\text { method }\end{array}$ & Product & Precursor & Process & References \\
\hline $\begin{array}{l}\text { Mechanochemical } \\
\text { method }\end{array}$ & $\mathrm{Na}_{0.88} \mathrm{WO}_{3}$ powder & Na pieces, $\mathrm{WO}_{3}$ powders & At $200 \mathrm{rpm}$ with Ar for $44 \mathrm{~h}$ & Wang et al., 2003 \\
\hline $\begin{array}{l}\text { Chemical vapor } \\
\text { transport }\end{array}$ & $\mathrm{M}_{\times} \mathrm{WO}_{3}$ crystal $(\mathrm{M}=\mathrm{Cs}, \mathrm{Rb}, \mathrm{K})$ & $\mathrm{K}_{2} \mathrm{WO}_{4}, \mathrm{KI}, \mathrm{Rb}_{2} \mathrm{WO}_{4}, \mathrm{Cs}_{2} \mathrm{WO}_{4}$ & Transport agent: $\mathrm{HgCl}_{2}, \mathrm{HgBr}_{2}, \mathrm{Cl}_{2}$ & Hussain et al., 1997 \\
\hline \multirow[t]{2}{*}{$\begin{array}{l}\text { Solid phase } \\
\text { reaction }\end{array}$} & $\mathrm{M}_{\mathrm{x}} \mathrm{WO}_{3} \operatorname{powder}(\mathrm{M}=\mathrm{Cs}, \mathrm{Rb}, \mathrm{Na}, \mathrm{K})$ & $\begin{array}{l}\left(\left(\mathrm{NH}_{4}\right)_{10} \mathrm{H}_{2}\left(\mathrm{~W}_{2} \mathrm{O}_{7}\right)_{6}, \mathrm{Cs}, \mathrm{Rb}, \mathrm{Na}\right. \\
\text { K-salts }\end{array}$ & $\begin{array}{l}\text { Heated at } 550^{\circ} \mathrm{C} \text { with } \mathrm{H}_{2} / \mathrm{N}_{2} \text { or } \\
\mathrm{H}_{2} / \mathrm{Ar} \text { for } 1 \mathrm{~h} \\
\text { Annealing at } 800^{\circ} \mathrm{C} \text { with } \mathrm{N}_{2} \text { or } \mathrm{Ar} \\
\text { for } 1 \mathrm{~h}\end{array}$ & $\begin{array}{l}\text { Takeda and Adachi, } 2007 \\
\text { Lee et al., 2014b } \\
\text { Guo et al., 2011a }\end{array}$ \\
\hline & $\begin{array}{l}\mathrm{Cs}_{0.33} \mathrm{WO}_{3} \text { powder } \\
\mathrm{Na}_{0.11} \mathrm{Cs}_{0.22} \mathrm{WO}_{3} \text { powder }\end{array}$ & $\begin{array}{l}\left(\mathrm{NH}_{4}\right)_{6} \mathrm{~W}_{12} \mathrm{O}_{39} \cdot \mathrm{xH}_{2} \mathrm{O} \mathrm{Cs}_{2} \mathrm{CO}_{3} \\
\mathrm{Na}_{2} \mathrm{CO}_{3}\end{array}$ & $\begin{array}{l}\text { Heated at } 550^{\circ} \mathrm{C} \text { with } \mathrm{H}_{2} / \mathrm{Ar} \text { for } 1 \mathrm{~h} \\
\text { Annealed at } 800^{\circ} \mathrm{C} \text { with } \mathrm{Ar} \text { for } 1 \mathrm{~h}\end{array}$ & Moon et al., 2013 \\
\hline $\begin{array}{l}\text { Inductively } \\
\text { coupled thermal } \\
\text { plasma method }\end{array}$ & $\mathrm{M}_{\mathrm{x}} \mathrm{WO}_{3}$ powder $\mathrm{M}=\mathrm{Cs}, \mathrm{Na}, \mathrm{K}$ & $\begin{array}{l}\left(\mathrm{NH}_{4}\right)_{10}\left(\mathrm{H}_{2} \mathrm{~W}_{12} \mathrm{O}_{42}\right) \cdot 4 \mathrm{H}_{2} \mathrm{O} \\
\mathrm{HCOOCs}, \mathrm{Na} 2 \mathrm{CO} 3, \mathrm{~K} 3 \mathrm{C} 6 \mathrm{H} 5 \mathrm{O} 7\end{array}$ & $\begin{array}{l}\text { Central gas: } \mathrm{Ar} \\
\text { Sheath gas: } \mathrm{H}_{2}\end{array}$ & Mamak et al., 2010 \\
\hline \multirow{4}{*}{$\begin{array}{l}\text { Hydrothermal } \\
\text { method }\end{array}$} & $\mathrm{Cs}_{0.33} \mathrm{WO}_{3}$ & $\mathrm{Cs}_{2} \mathrm{WO}_{4}, \mathrm{WO}_{2}, \mathrm{WO}_{3}, \mathrm{H}_{2} \mathrm{O}$ & Heated at $800{ }^{\circ} \mathrm{C}$ for $24 \mathrm{~h}$ & Okusako et al., 2012 \\
\hline & $\mathrm{K}_{0.26} \mathrm{WO}_{3}$ nanorod & $\mathrm{K}_{2} \mathrm{WO}_{4}, \mathrm{~K}_{2} \mathrm{SO}_{4}, \mathrm{H}_{2} \mathrm{O}$ & $\begin{array}{l}\text { Heated at } 200^{\circ} \mathrm{C} \text { for } 24 \mathrm{~h} \text { were } \\
\text { post-calcine }\end{array}$ & Wu et al., 2017b \\
\hline & $\left(\mathrm{NH}_{4}\right)_{0.33} \mathrm{WO}_{3}$ nanorod & $\begin{array}{l}(\mathrm{NH} 4) 10 \cdot 4 \mathrm{H} 2 \mathrm{O} \text {, Ethylene glycol, } \\
\mathrm{CH}_{3} \mathrm{COOH}\end{array}$ & Heated at $200^{\circ} \mathrm{C}$ for $72 \mathrm{~h}$ & $\begin{array}{l}\text { Guo et al., } 2012 a \\
\text { Wu et al., } 2017 b\end{array}$ \\
\hline & $\mathrm{K}_{0.26} \mathrm{WO}_{3}$ nanowire & $\mathrm{K}_{2} \mathrm{WO}_{4}, \mathrm{EDA}, \mathrm{H}_{2} \mathrm{O}$ & $\begin{array}{l}\text { Heated at } 250^{\circ} \mathrm{C} \text { for } 48 \mathrm{~h} \\
\text { (Electrostatic-induced) }\end{array}$ & Liu et al., 2013a \\
\hline \multirow{3}{*}{$\begin{array}{l}\text { Solvothermal } \\
\text { method }\end{array}$} & $\mathrm{Cs}_{0.3} \mathrm{WO}_{3}$ powder & $\mathrm{WCl}_{6}, \mathrm{CsOH}$, Ethanol & Heated at $200^{\circ} \mathrm{C}$ for $12 \mathrm{~h}$ & Liu et al., 2010 \\
\hline & $\mathrm{Cs}_{0.32} \mathrm{WO}_{3}$ powder & $\mathrm{H}_{2} \mathrm{WO}_{4}, \mathrm{H}_{2} \mathrm{O}_{2}, \mathrm{CsCl}$, Oleic acid & Heated at $220-280^{\circ} \mathrm{C}$ for $4 \mathrm{~h}$ & Yao et al., 2018 \\
\hline & $\mathrm{M}_{0.33} \mathrm{WO}_{3}$ nanorod $(\mathrm{M}=\mathrm{Rb}, \mathrm{Cs})$ & $\begin{array}{l}\mathrm{WCl}_{6}, \mathrm{RbOH}, \mathrm{CsOH} \text { Ethanol, } \\
\mathrm{CH}_{3} \mathrm{COOH}\end{array}$ & $\begin{array}{l}\text { Heated at } 200-240^{\circ} \mathrm{C} \text { for } 20 \mathrm{~h} \\
\text { (Water controlled-release) }\end{array}$ & $\begin{array}{l}\text { Wu et al., 2017b } \\
\text { Guo et al., } 2010\end{array}$ \\
\hline
\end{tabular}

and $\mathrm{K} 3 \mathrm{C} 6 \mathrm{H} 5 \mathrm{O} 7$ in a varied ratio of $\mathrm{W}$ and $\mathrm{M}$ were used. However, Ar was used as the central gas along with a small amount of $\mathrm{H}_{2}$ to provide the reducing environment required for the synthesis of $\mathrm{M}_{\mathrm{x}} \mathrm{WO}_{3}$. A mixture of tungsten and alkali salts with low decomposition temperature was used as the precursor. Thermal plasma synthesis has advantages in terms of material handling, raw material cost, and processing throughput. Inductively coupled thermal plasma (ICTP) synthesis has proven to be a unique method for the high throughput production of $\mathrm{M}_{\mathrm{x}} \mathrm{WO}_{3}$, where $\mathrm{M}=\mathrm{Na}, \mathrm{K}$, and $\mathrm{Cs}$ tungsten bronze nanopowders were synthesized at a high purity, using low-cost precursor materials. In general, materials produced by thermal plasma have a favorable optical absorption, high purity, and a tunable composition when using low-cost precursor materials. Major applications include coatings and heat shielding filters, as they exhibit a high extinction coefficient in the NIR region with little effect on transparency or visible color. ICTP is a fast reaction method for high production at low temperatures. It has high potential and can be used extensively in future research.

\section{Hydrothermal Method}

The hydrothermal method is simple and versatile for use in the synthesis of inorganic nanomaterials from aqueous solutions under high-temperature and high-pressure conditions. Temperature, pressure, and precursor concentration are the parameters that must be adjusted to the characteristics of nanomaterials. Water is the most commonly used solvent in the hydrothermal process. The water density and the dielectric constant are highly dependent on the temperature and pressure. A drop in the dielectric water constant is closely linked to an increase in temperature and a decrease in pressure. As the dielectric constant of water decreases, the reaction rate is enhanced considerably and thus the nucleation growth of crystals is facilitated. It offers many advantages such as a onestep synthetic procedure, environmental friendliness, production feasibility, good dispersion in solutions, and inexpensive instrumentation. Moreover, this method avoids the use of $\mathrm{H}_{2}$ and considerably improves safety. However, it induces hightemperature energy consumption. Tungsten bronze such as $\mathrm{Cs}_{0.33} \mathrm{WO}_{3}, \mathrm{~K}_{0.26} \mathrm{WO}_{3}$ nanorods and $\left(\mathrm{NH}_{4}\right)_{0.33} \mathrm{WO}_{3}$ nanorods have been reported by hydrothermal method. For the preparation of $\mathrm{Cs}_{0.33} \mathrm{WO}_{3}$, the precursor $\mathrm{Cs}_{2} \mathrm{WO}_{4}, \mathrm{WO}_{2}, \mathrm{WO}_{3}$, and distilled water were mixed and heated at $800^{\circ} \mathrm{C}$ for $24 \mathrm{~h}$ (Okusako et al., 2012). $\mathrm{K}_{0.26} \mathrm{WO}_{3}$ nanorods were synthesized with $\mathrm{K}_{2} \mathrm{WO}_{4}$, $\mathrm{K}_{2} \mathrm{SO}_{4}$, and distilled water at $200^{\circ} \mathrm{C}$ for $24 \mathrm{~h}$ and further postcalcined at $600^{\circ} \mathrm{C}$ for $2 \mathrm{~h}$ under an atmosphere of $\mathrm{H}_{2}$ (5 vol\%)/ $\mathrm{N}_{2}$ (Wu et al., 2017b). For the synthesis of $\left(\mathrm{NH}_{4}\right)_{0.33} \mathrm{WO}_{3}$ nanorods, ammonium paratungstate, ethylene glycol, and acetic acid were mixed and heated at $200^{\circ} \mathrm{C}$ for $72 \mathrm{~h}$ (Guo et al., 2012a). Liu et al. (2013a) reported the synthesis of $\mathrm{K}_{0.26} \mathrm{WO}_{3}$ nanowires by an electrostatic-induced process using $\mathrm{K}_{2} \mathrm{WO}_{4}$ as a precursor along with ethylenediamine (EDA) and water. It was heated further in an electric oven at $250^{\circ} \mathrm{C}$ for $48 \mathrm{~h}$. EDA served as a reducing agent, which is much milder compared to other reducing agents such as $\mathrm{NaBH}_{4}$ (Zhu and Manthiram, 1994) or $\mathrm{N}_{2} \mathrm{H}_{4}$ (Yang et al., 2003) used in the preparation of 
tungsten bronzes. In fact, it is important to note from these preparations that different nanoparticles have different reaction schemes and processing conditions. Therefore, determining the proper chemical reactions with suitable conditions for different nanoparticles is desirable.

\section{Solvothermal Method}

The solvothermal method uses ethanol and ethylene glycol instead of water as a solvent to achieve the dual role of solvent and reducing agent. The control variables can be varied by adjusting the solvent type, changing the reaction atmosphere, and using different surfactants, $\mathrm{pH}$, reactant concentration, and filled volume of autoclave. The $\mathrm{Cs}_{0.3} \mathrm{WO}_{3}$ powder was synthesized by a normal solvothermal reaction with the precursor of $\mathrm{WCl}_{6}$, where their metal hydroxides $(\mathrm{CsOH})$ were mixed with ethanol and heated at $200^{\circ} \mathrm{C}$ for $12 \mathrm{~h}$ and further annealed in the $\mathrm{NH}_{3}$ atmosphere at $500^{\circ} \mathrm{C}$ for $1 \mathrm{~h}$ (Liu et al., 2010). $\mathrm{Cs}_{0.32} \mathrm{WO}_{3}$ powder was also synthesized by a $\mathrm{H}_{2} \mathrm{WO}_{4}$ precursor heated at $220^{\circ} \mathrm{C}$ for $4 \mathrm{~h}$ (Yao et al., 2018). To control the water releasing process, which is based on an esterification reaction between ethanol and acetate acid, monodispersed nanorods of $\mathrm{M}_{\mathrm{x}} \mathrm{WO}_{3}$ $(\mathrm{M}=\mathrm{Cs}$ and $\mathrm{Rb}$ ) were produced (Guo et al., 2010; $\mathrm{Wu}$ et al., 2017b). An ethanol solution of $\mathrm{WCl}_{6}$ and $\mathrm{CsOH}$ was mixed with $\mathrm{CH}_{3} \mathrm{COOH}$ and heated at $200^{\circ} \mathrm{C}$ for $20 \mathrm{~h}$. In this method, the heat treatment temperature is reduced by replacing it with ethanol as compared to the hydrothermal method. Moreover, the ethanol solvent serves a multifunctional property to control the morphology and to decrease the heat treatment temperature. Thus, it overcomes the high temperature energy consumption using a low temperature. However, comparatively, the hydrothermal method has a reduced environmental impact.

Figure 2 demonstrates different morphologies of $\mathrm{WO}_{2.72}$ with the function of reaction time. This shows a morphological evolution from nanoparticles to urchin nanostructures ( $\mathrm{Su}$ and Lin, 2009; Guo et al., 2012c; Moshofsky and Mokari, 2012). Table 2 presents a brief summary of the nanostructured $\mathrm{WO}_{2.72}$ types that were prepared by CVT and solid-phase reaction. $\mathrm{W} / \mathrm{WO}_{2.72}$ heterostructures (Liu et al., 2013b) $\left(\mathrm{WO}_{2.72}\right.$ nanowires grown on the side surface of the $\mathrm{W}$ whiskers along the radial direction), $\mathrm{WO}_{2.72}$ nanoneedles (Jin et al., 2004), $\mathrm{WO}_{2.72}$ sub-micro fibers (Liu et al., 2012), and $\mathrm{WO}_{2.72}$ tapered needles (Wang et al., 2007) were synthesized using $\mathrm{WO}_{3}$ as a precursor by a two-step CVT method. In general, the temperature of the furnace was increased from the room temperature to $800-$ $1000^{\circ} \mathrm{C}$. $\mathrm{WO}_{2.72}$ nanoparticles were reported by the solid-phase reaction method using $\mathrm{WCl}_{6}$ as a raw material with ethanol (Venables and Brown, 1996; Takeda and Adachi, 2007). Ma et al. (2017) prepared $\mathrm{WO}_{2.72}$ nanoparticles using $\mathrm{WCl}_{6}$ and ethanol with $\mathrm{NH}_{3}$ solution as a solvent, which was pyrolyzed under air atmosphere. Because ammonia molecules tend to chelate strongly with tungsten ions, they could work as capping agents to hinder particle growth.

A brief summary of the preparation of $\mathrm{WO}_{2.72}$ nanostructures by hydrothermal and solvothermal methods are listed in Table 3. $\mathrm{WO}_{2.72}$ nanorods have been reported by the hydrothermal method using $\mathrm{H}_{2} \mathrm{WO}_{4}$ and $\mathrm{Na}_{2} \mathrm{SO}_{4}$ at $160^{\circ} \mathrm{C}$ for $24 \mathrm{~h}$ (Lou and Zeng, 2003). Guo et al. (2011b) reported $\mathrm{WO}_{2.72}$ nanorods synthesized hydrothermally by reducing the as-obtained $\left(\mathrm{NH}_{4}\right)_{\mathrm{x}} \mathrm{WO}_{3+\mathrm{x} / 2}$ and using sulfate as a capping agent in an atmosphere of $\mathrm{H}_{2}(5 \mathrm{vol} \%) / \mathrm{N}_{2}$ at $500^{\circ} \mathrm{C}$ for $1 \mathrm{~h}$. The solvothermal method was extensively studied for $\mathrm{WO}_{2.72}$ for different nanostructures. $\mathrm{WO}_{2.72}$ nanowires were synthesized by a simple solvothermal method using $\mathrm{WCl}_{6}$ and ethanol solution under $180^{\circ} \mathrm{C}$ for $10-24 \mathrm{~h}$ (Qin et al., 2011b; Xi et al., 2012; Guo et al., 2016). Cetyltrimethylammonium bromide has also been used as a growth-directing agent to fabricate $\mathrm{WO}_{2.72}$ nanowires (Li et al., 2016a). Huang et al. (2014a) synthesized $\mathrm{WO}_{2.72}$ nanowires by using $\mathrm{WCl}_{6} / \mathrm{NaNO}_{3}$ through $\mathrm{NO}_{3}^{-}$-mediated assembly. With an increase in the $\mathrm{NO}_{3}^{-}$concentration, the uniformity of the $\mathrm{WO}_{2.72}$ alignments was enhanced, clearly demonstrating the process of $\mathrm{NO}_{3}^{-}$-medicated orientation. $\mathrm{Li}$ et al. (2016b) fabricated $\mathrm{WO}_{2.72}$ nanofibers by using $\mathrm{WCl}_{6}$ with oleic acid and $2.5 \mathrm{~mL}$ tri-n-octylamine under $350^{\circ} \mathrm{C}$ for $1 \mathrm{~h}$. $\mathrm{WO}_{2.72}$ nanowire bundles were synthesized with $\mathrm{WCl}_{6}$ and propanol solvent at $200^{\circ} \mathrm{C}$ for $9 \mathrm{~h}$, and the product was annealed in air at $250-450{ }^{\circ} \mathrm{C}$ for $2 \mathrm{~h}$ (Qin et al., 2011b). A different morphology was reported when varying the annealing temperature from 250 to $550^{\circ} \mathrm{C}$. It was found that nanowires remain unchanged by the annealing treatment at 250 and $350^{\circ} \mathrm{C}$. However, annealing at 450 and $550{ }^{\circ} \mathrm{C}$ induced $\mathrm{WO}_{3}$ nanobelt-like structures. The Fabrication of mesoporous $1 \mathrm{D}-\mathrm{WO}_{2.72}$ nanobelts was conducted using a solvothermal method mixed with $\mathrm{WO}_{3}$, polyvinyl pyrrolidone, and EDA at $180^{\circ} \mathrm{C}$ for $12 \mathrm{~h}$, calcined at $\mathrm{Ar} / \mathrm{H}_{2}$ atmosphere at $580^{\circ} \mathrm{C}$ for $3 \mathrm{~h}$ (Sun et al., 2016). 3D $\mathrm{WO}_{2.72}$ networks were obtained by solvothermally treating $\mathrm{WCl}_{6}$ in ethanol at $160^{\circ} \mathrm{C}$ (Bai et al., 2013). The results showed that high precursor concentration contributed to the formation of $\mathrm{WO}_{2.72}$ networks. However, when the concentration was further increased, plate-like $\mathrm{WO}_{2.72}$ was found at a lower concentration. Sea-urchin-like structures composed of radial nanowires were obtained. $\mathrm{WO}_{2.72}$ nanocrystals were synthesized by treating the precursor of $\mathrm{WCl}_{6}$ and ethanol under $200^{\circ} \mathrm{C}$ for $24 \mathrm{~h}$ (Guo et al., 2012c). The effect of the tungsten precursor on the morphology was investigated in this case. Similar experiments were conducted using mixtures of $\mathrm{WCl}_{6}$ and tungsten (VI) ethoxide $\left(\mathrm{W}(\mathrm{EtO})_{6}\right)$ with varied molar ratios, $\mathrm{WO}_{2.72}$ nanorods were obtained with sizes ranging from 300 to $600 \mathrm{~nm}$ when mixtures of $5 \mathrm{mM} \mathrm{W}(\mathrm{EtO})_{6}$ and $10 \mathrm{mM} \mathrm{WCl}_{6}$ were used as the tungsten source. However, when equimolar mixtures of $\mathrm{W}(\mathrm{EtO})_{6}$ and $\mathrm{WCl}_{6}(7.5 \mathrm{mM})$ were used, plate-like particles with sizes of $300-500 \mathrm{~nm}$ were obtained. As the concentration of $\mathrm{W}(\mathrm{EtO})_{6}$ was increased to $50 \mathrm{mM}$, well-defined monodispersed microspheres of $0.5-2 \mu \mathrm{m}$ diameter were formed. It was suggested this might be because of the rate of water generation from different tungsten sources, and the difference in the hydrolysis behavior between $\mathrm{W}(\mathrm{EtO})_{6}$ and $\mathrm{WCl}_{6}$ resulted in different morphologies of $\mathrm{WO}_{3-\mathrm{x}}$. Mesoporous sphere $3 \mathrm{D} \mathrm{WO}_{2.72}$ was formed by using $\mathrm{WCl}_{6}$ as a precursor mixed with solvent ethanol and $\mathrm{CH}_{3} \mathrm{COOH}$ at $180^{\circ} \mathrm{C}$ for $16 \mathrm{~h}$ (Huang et al., 2014b; Zhao et al., 2017). At low precursor concentrations, only semi-closed spheres and disordered nanoparticles were formed. At higher concentration, hollow spheres were formed very easily that were bigger and had thicker shells. Only disordered nanoparticles were formed at a low 


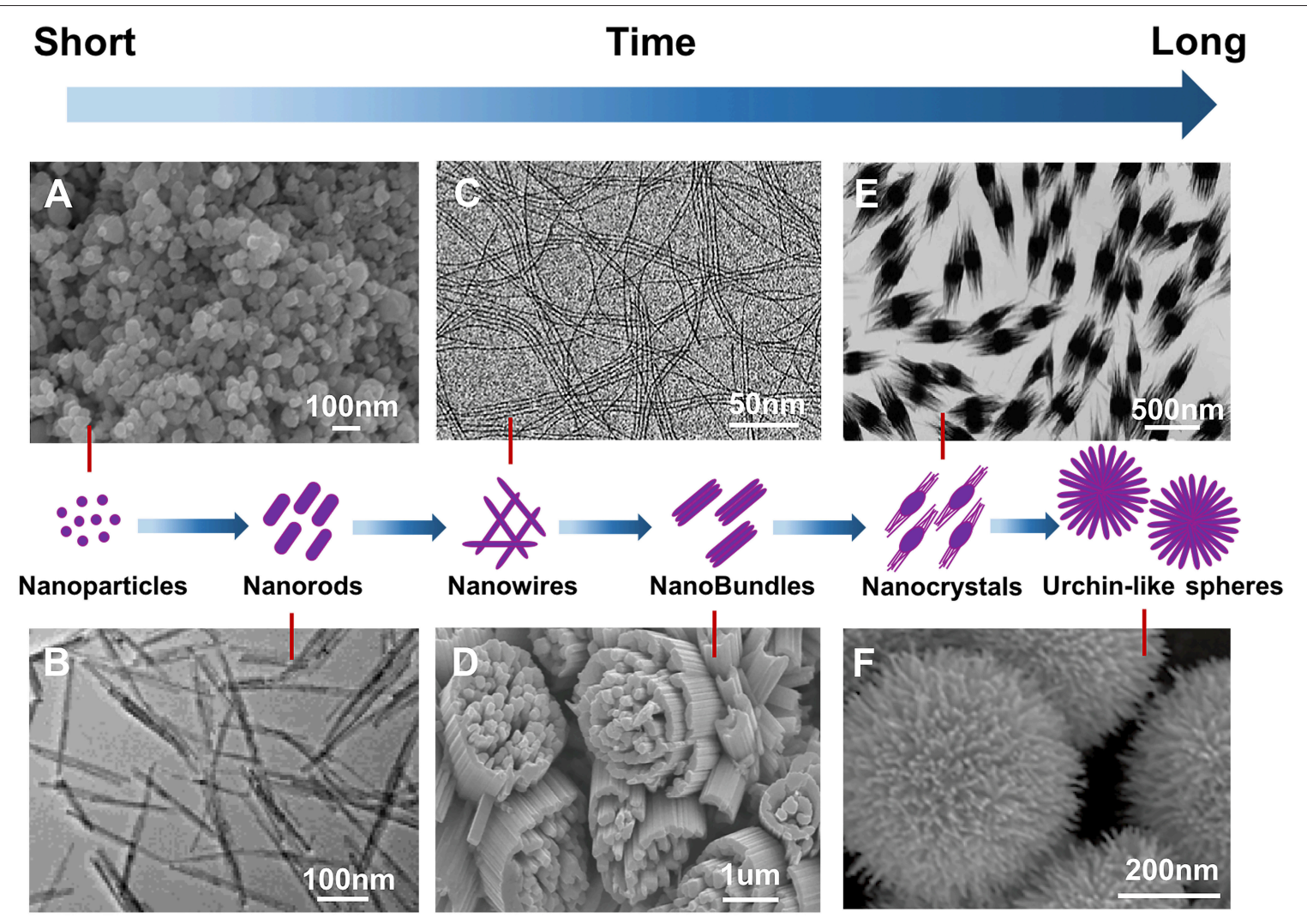

FIGURE 2 | Morphologies of $\mathrm{WO}_{2.72}$ prepared with different reaction time. (A) nanoparticles, (B) nanorods, (C) nanowires. Reproduced with permission (Moshofsky and Mokari, 2012). Copyright 2012, Chemistry of Materials. (D) nanobundles. Reproduced with permission (Su and Lin, 2009). Copyright 2009, The Journal of Physical Chemistry C. (E) nanocrystals. Reproduced with permission (Guo et al., 2012c) Copyright 2012, American chemical society (ACS), and (F) urchin-like spheres.

TABLE 2 | Preparations of non-stoichiometric tungsten-oxide $\left(\mathrm{WO}_{2.72}\right)$ by chemical vapor transport and solid phase reaction.

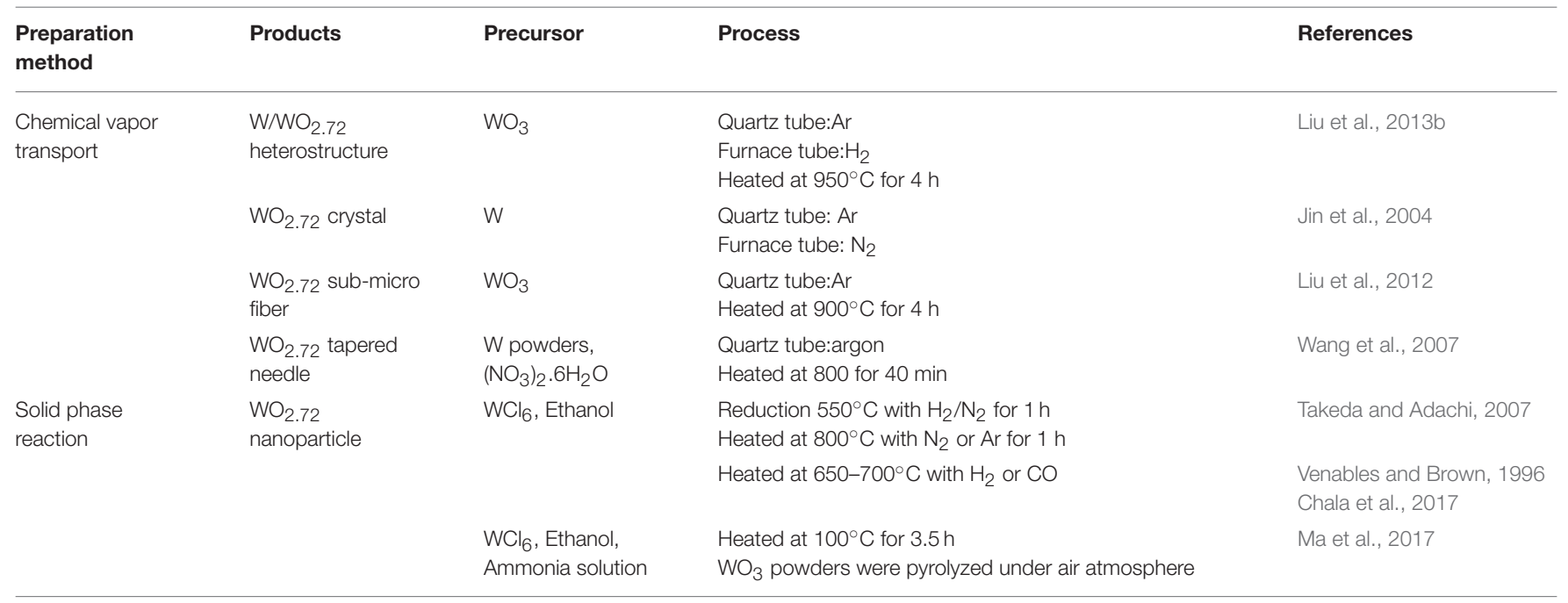

temperature $\left(120^{\circ} \mathrm{C}\right)$ even when sufficient $\mathrm{WCl}_{6}$ was provided. This demonstrated that the morphology can be fine-tuned by controlling variables such as time, precursor concentration, and temperature (Guo et al., 2016). synthesized $\mathrm{WO}_{2.72}$ urchin-like nanostructures and nanowires by treating $\mathrm{WCl}_{6}$ with ethanol under $180^{\circ} \mathrm{C}$ for $10 \mathrm{~h}$. $\mathrm{WO}_{2.72}$ nanowires were obtained when the precursor concentration was $0.5 \mathrm{~g} \mathrm{~L}^{-1}$ and the reaction time was $10 \mathrm{~h}$. Control of different morphologies by adjusting the concentration of precursor was discussed in this study. When the precursor concentration increased to $1 \mathrm{~g} \mathrm{~L}^{-1}$, the 
TABLE 3 | Preparations of non-stoichiometric tungsten-oxide $\left(\mathrm{WO}_{2.72}\right)$ by hydrothermal and solvothermal methods.

\begin{tabular}{|c|c|c|c|c|}
\hline Preparation method & Products & Precursor & Process & References \\
\hline \multirow[t]{2}{*}{ Hydrothermal } & $\mathrm{WO}_{2.72}$ nanorod & $\mathrm{H}_{2} \mathrm{WO}_{4} \cdot \mathrm{xH}_{2} \mathrm{O}, \mathrm{Na}_{2} \mathrm{SO}_{4}$ & Heated at $160-200^{\circ} \mathrm{C}$ for $24 \mathrm{~h}$ & Lou and Zeng, 2003 \\
\hline & & $\mathrm{Na}_{2} \mathrm{WO}_{4},\left(\mathrm{NH}_{4}\right)_{2} \mathrm{SO}_{4}$ & $\begin{array}{l}\text { Heated at } 200 \circ \mathrm{C} \text { for } 24 \mathrm{~h} \\
\text { Heated at } 500 \circ \mathrm{C} \text { with } \mathrm{H}_{2} / \mathrm{N}_{2} \text { for } 1 \mathrm{~h}\end{array}$ & Guo et al., 2011b \\
\hline \multirow[t]{10}{*}{ Solvothermal process } & $\mathrm{WO}_{2.72}$ nanowire & $\mathrm{WCl}_{6}$, Ethanol & Heated at $180^{\circ} \mathrm{C}$ for $10-24 \mathrm{~h}$ & $\begin{array}{l}\text { Guo et al., } 2016 \\
\text { Xi et al., } 2012 \\
\text { Late et al., } 2010\end{array}$ \\
\hline & & $\mathrm{WCl}_{6}$, Ethanol, CTAB & Heated at $180^{\circ} \mathrm{C}$ for $18 \mathrm{~h}$ & Li et al., 2016a \\
\hline & & $\mathrm{WCl}_{6}, \mathrm{n}$-propanol, $\mathrm{NaNO}_{3}$ & Heated at $200^{\circ} \mathrm{C}$ for $24 \mathrm{~h}$ & Huang et al., 2014a \\
\hline & $\mathrm{WO}_{2.72}$ nanofiber & $\begin{array}{l}\text { WCl}_{6}, \text { Oleic acid, } \\
\text { Tri-n-octylamine. }\end{array}$ & Heated at $350^{\circ} \mathrm{C}$ for $1 \mathrm{~h}$ & Li et al., 2016b \\
\hline & $\mathrm{WO}_{2.72}$ nanowire bundle & $\mathrm{WCl}_{6}$, Propanol & $\begin{array}{l}\text { Heated at } 200^{\circ} \mathrm{C} \text { for } 9 \mathrm{~h} \\
\text { Annealed at } 450^{\circ} \mathrm{C} \text { with air for } 2 \mathrm{~h}\end{array}$ & Qin et al., 2011b \\
\hline & $\begin{array}{l}\text { Mesoporous } \mathrm{WO}_{2.72} \\
\text { nanobelt }\end{array}$ & $\begin{array}{l}\mathrm{WO}_{3} \text {, Polyvinyl pyrrolidone, } \\
\text { EDA }\end{array}$ & $\begin{array}{l}\text { Heated at } 180^{\circ} \mathrm{C} \text { for } 12 \mathrm{~h} \\
\text { Annealed at } 580^{\circ} \mathrm{C} \text { with } \mathrm{Ar} / \mathrm{H}_{2} \text { for } 3 \mathrm{~h}\end{array}$ & Sun et al., 2016 \\
\hline & $\mathrm{WO}_{2.72}$ nanowire network & $\mathrm{WCl}_{6}$, Ethanol & Heated at $160^{\circ} \mathrm{C}$ & Bai et al., 2013 \\
\hline & $\mathrm{WO}_{2.72}$ nanocrystal & $\mathrm{WCl}_{6}$, Ethanol & Heated at $200^{\circ} \mathrm{C}$ for $24 \mathrm{~h}$ & Guo et al., 2012c \\
\hline & $\begin{array}{l}\text { Mesoporous } \mathrm{WO}_{2.72} \\
\text { nanosphere }\end{array}$ & $\mathrm{WCl}_{6}$, Ethanol, $\mathrm{CH}_{3} \mathrm{COOH}$ & Heated at $180^{\circ} \mathrm{C}$ for $16 \mathrm{~h}$ & $\begin{array}{l}\text { Huang et al., } 2014 b \\
\text { Zhao et al., } 2017\end{array}$ \\
\hline & urchin-like $\mathrm{WO}_{2.72}$ & $\mathrm{WCl}_{6}$, Ethanol & Heated at $180^{\circ} \mathrm{C}$ for $10 \mathrm{~h}$ & Guo et al., 2016 \\
\hline
\end{tabular}

$\mathrm{WO}_{2.72}$ nanowires changed to bundle-like $\mathrm{WO}_{2.72}$. When the concentration was further increased to $3 \mathrm{~g} \mathrm{~L}^{-1}$, a mixture of urchin-like nanostructures and nanowires was obtained. Once the concentration reached $5 \mathrm{~g} \mathrm{~L}^{-1}$, nanospheres were obtained. The results showed that urchin-like $\mathrm{WO}_{2.72}$ nanostructures have a better light harvesting capacity in the IR region than nanowires. The mechanism of different nanostructures proposed as $\mathrm{WO}_{2.72}$ nanocrystals would preferably grow in the [010] direction as nanowires. Because the diameter of the nanowires was very small (with a large surface energy), the nanowires became bundlelike $\mathrm{WO}_{2.72}$ (thus reducing the surface energy). As a result, bundle-like $\mathrm{WO}_{2.72}$ nanostructures continued to be packaged and developed into urchin-like $\mathrm{WO}_{2.72}$ nanostructures. Urchins were thus formed and further developed into nanospheres. Zhao et.al reported that $\mathrm{WO}_{2.72}$ architectures including nanofibers, nanofiber bundles, and sea urchin-like microspheres were prepared by a template-free solvothermal method that tuned the $\mathrm{WCl}_{6}$ concentrations (Zhao et al., 2017). In fact, it is important to note from these reports that different nanoparticles have different reaction schemes and processing conditions. Therefore, the proper chemical reactions with suitable conditions for different nanoparticles must be determined. Compared with the methods previously mentioned, solvothermal treatment is a facile, cost-effective, and well-studied liquid-phase technique, which has the capability of producing $\mathrm{WO}_{\mathrm{x}}$ with different nanomorphologies.

\section{APPLICATIONS OF TUNGSTEN-OXIDE-BASED MATERIALS}

Tungsten-oxide-based materials $\mathrm{WO}_{2.72}, \mathrm{M}_{\mathrm{X}} \mathrm{WO}_{3}$, and their hybrids have attracted considerable attention in various fields such as heat generation, photocatalysis, and energy-related and gas-sensor applications. These applications are both important and interesting. They are discussed in more detail as follows.

\section{Heat Generation}

Heat generation is emerging as a promising technology and one of its important practical applications is in manufacturing polyethylene terephthalate (PET) bottles. An extruder PET preform is heated above its glass transition ( $\mathrm{Tg}$ ) point by IR irradiation so than it can be blown into the required shape. A small amount of $\mathrm{WO}_{3}$ is incorporated into the PET to reduce the IR irradiation time and thus speed up productivity. The photothermal conversion properties of $\mathrm{WO}_{2.7}$ show much greater potential in heat generation. A rise in temperature in a short span of time further reduces the IR irradiation time with $\mathrm{WO}_{2.72}$. This could considerably improve the productivity of PET bottles. Considering their potential in harvesting solar energy and in heat conversion, various applications such as thermo/pyroelectricity, water evaporation, and NIR shielding are discussed.

\section{Thermo/Pyroelectricity}

Thermoelectric technology has been widely used as a means to convert heat into electrical energy through the Seebeck effect. Pyroelectricity is one of the least-known properties of certain solids and condensed materials. This property pertains to temperature-dependent spontaneous polarization in certain anisotropic solids and refers to the ability of a certain class of materials to generate an electric charge when heated and cooled consecutively. The temperature variations slightly modify the position of atoms within the crystal structure causing effects such as polarization change. The change in polarization creates a voltage across the material. Thus, it can be used 
as a thermal-electric converter. However, achieving a high temperature difference in a non-conducted way is difficult. Therefore, it cannot be efficiently used to convert thermal energy into electric energy through a time-dependent temperature variation with spatial uniformity. To this end, PTM $\mathrm{WO}_{2.72}$ incorporated within an electrospun pyroelectric polyvinylidene difluoride (PVDF) fiber membrane were prepared. Schematics of the pyroelectric measurement are shown in Figure 3A. Here, a higher temperature variation was obtained by irradiating NIR light in an on-off sequence on $\mathrm{WO}_{2.72}$ /PVDF fiber membranes. This resulted in higher output voltages compared to the fiber membranes without $\mathrm{WO}_{2.72}$ (Figure 3B) (Wu et al., 2017a). Steady reproducibility of temperature variation and higher output voltages are shown as well. The results demonstrate that the $\mathrm{WO}_{2.72} / \mathrm{PVDF}$ materials can be used for NIR sensing and solar energy harvester applications (Wu et al., 2017a). It is worth noting that hybrids of $\mathrm{WO}_{3}$ have recently gained attention in thermo/pyroelectric studies. However, $\mathrm{WO}_{2.72}$ and $\mathrm{M}_{\mathrm{x}} \mathrm{WO}_{3}$ (their hybrids) are yet to be explored.

\section{Water Evaporation}

A solar-driven water evaporation process that utilizes sunlight as a renewable energy resource can be used in numerous practical applications. Such applications include freshwater production, desalination, and distillation (Hua et al., 2017; Shang et al., 2017; Awad et al., 2018; Kim et al., 2018). Solar heating designed as "airwater interface solar heating" has the ability to trap a wide solar spectrum selectively by strengthening the air-water interface (Wang et al., 2017d). However, heat transfer minimizes from interfacial to underlying bulk water. The photothermal layer that induces self-floating on the top of a water surface is deliberately designed as a heat barrier, that introduced interfacial heating in solar thermal applications (Liu et al., 2015; Lou et al., 2016). To include multifunctionality in a single-component material, multilayered materials offer researchers the opportunity to design more practical solutions, as demonstrated in our recent work. We had efficiently utilized $\mathrm{WO}_{2.72}$ photothermal materials with polylactic acid (PLA). The photoabsorption properties of these photothermal materials made them suitable for converting light energy to thermal energy (Chala et al., 2018a). These composites were designed as fiber membranes that have a self-floating ability and act as heat barriers at air-water interfaces for lightdriven water evaporation. Figure 4A shows a schematic of the experimental setup used for this measurement. For $\mathrm{WO}_{2.72} / \mathrm{PLA}$, a rapid rise of temperature $\Delta \mathrm{T}$ can be seen from $19.4^{\circ} \mathrm{C}$ to $44.7^{\circ} \mathrm{C}$ and then to $75.3^{\circ} \mathrm{C}$ for over $5 \mathrm{~min}$ of irradiation containing 0 , 4 , and $7 \mathrm{wt} \%$ of $\mathrm{WO}_{2.72}$ nanoparticles, respectively, as shown in Figure 4B. The water evaporation efficiency of the $\mathrm{WO}_{2.72} / \mathrm{PLA}$ fiber membrane containing $7 \mathrm{wt} \% \mathrm{WO}_{2.72}$ nanoparticles reached $81.39 \%$, which is significantly higher than pure water $39.09 \%$ (Figure 4C) (Chala et al., 2018a). These distinct properties of $\mathrm{WO}_{2.72}$ make it feasible for commercial applications such as steam generation, desalination, and sterilization.

$\mathrm{WO}_{\mathrm{x}}$ photothermal materials have been investigated by (Ming et al., 2018) for direct steam generation. In their study, under 1 sun illumination, water and $\mathrm{WOAr}_{2}$ nanofluids reached $34.3^{\circ} \mathrm{C}$ and $41.0^{\circ} \mathrm{C}$, respectively, after $1,800 \mathrm{~s}$. The solar evaporation effciency of $2 \mathrm{D}$ defective $\mathrm{WO}_{\mathrm{x}}$ nanofluids reached $78.6 \%$ compared to that of the water $(12.22 \%) . \mathrm{WO}_{2.72}$ and its hybrid recently gained interest for the study of water evaporation. It is worth noting that $\mathrm{WO}_{3}$ and $\mathrm{M}_{\mathrm{x}} \mathrm{WO}_{3}$ (their hybrids) are still unknown in this field. Therefore, the development of hybrids of photothermal materials in full spectrum solar light has become important in terms of energy conservation and sustainability for photothermal water evaporation, desalination, and steam generation.

\section{NIR Shielding}

NIR-shielding materials have received considerable attention for their use in developing transparent solar heat-shielding filters, which can be used for solar control windows in automobiles and buildings. $\mathrm{WO}_{3-\mathrm{x}}$ and $\mathrm{M}_{\mathrm{x}} \mathrm{WO}_{3}, \mathrm{M}=\mathrm{Na}^{+}$(Moon et al., 2013), $\mathrm{K}^{+}$(Guo et al., 2011a), Rb ${ }^{+}$(Guo et al., 2011a), Cs ${ }^{+}$(Zeng et al., 2015), and $\mathrm{NH}_{4}^{+}$(Huiyuan et al., 2018) are candidates for such applications. Among the many tungsten materials with a capability of shielding NIR light through absorption mechanism, cesium tungsten oxide (particularly $\mathrm{Cs}_{0.33} \mathrm{WO}_{3}$ ) nanoparticles are considered highly promising materials for transparent solar filter applications. Guo et al. developed $\mathrm{WO}_{2.72}$ nanorods coated on a quartz glass. Excellent heat-insulating performance was realized even after the $\mathrm{WO}_{2.72}$ nanorods on a quartz glass were irradiated for $1 \mathrm{~h}$, when the inner temperature was increased to only $26.2^{\circ} \mathrm{C}$, which was much lower than the temperatures reached using the quartz glass and indium-tin oxide glass (Figure 5) (Guo et al., 2012c). $\mathrm{Cs}_{\mathrm{x}} \mathrm{WO}_{3} / \mathrm{ZnO}$ composite films were found to be highly efficient for heat insulation because of the excellent NIR shielding properties of $\mathrm{Cs}_{\mathrm{x}} \mathrm{WO}_{3}$ (Wu et al., 2015). These composite films also showed good capacity to block harmful UV lights. The hybrids of $\mathrm{WO}_{3}$ and $\mathrm{M}_{\mathrm{x}} \mathrm{WO}_{3}$ for NIR shielding applications have been widely studied. However, to the best of our knowledge, $\mathrm{WO}_{2.72}$ and its hybrid have yet to be fully explored in this field.

\section{Photocatalysts}

Photochemical utilization of solar energy (i.e., photocatalytic degradation of organic pollutants, hydrogen production, photocatalytic reduction of $\mathrm{CO}_{2}$, and photocatalytic oxidation of alcohols) is being intensively studied (Wang et al., 2017c). Semiconductor materials such as for $\mathrm{WO}_{3-\mathrm{x}}$ and $\mathrm{M}_{\mathrm{x}} \mathrm{WO}_{3}$ have been widely used in many fields of photocatalysis, including air purification, wastewater treatment, anti-virus sterilization, photolysis of hydrogen and oxygen production, nitrogen oxide fixation, and remediation of crude oil spills. Five photochemical uses of solar energy for $\mathrm{WO}_{\mathrm{x}}$ and $\mathrm{M}_{\mathrm{x}} \mathrm{WO}_{3}$ materials are discussed as follows.

\section{Water Oxidation}

A water oxidation reaction acquires electrons from the earth's abundant water. An efficient water oxidation catalyst can provide the necessary electrons for proton reduction. However, in terms of effective utilization of solar light, the catalyst design concept requires light absorption characteristics in the visible light range. Water oxidation must meet one major thermodynamic criteria: the valence band (VB) level of a semiconductor should be more 
A

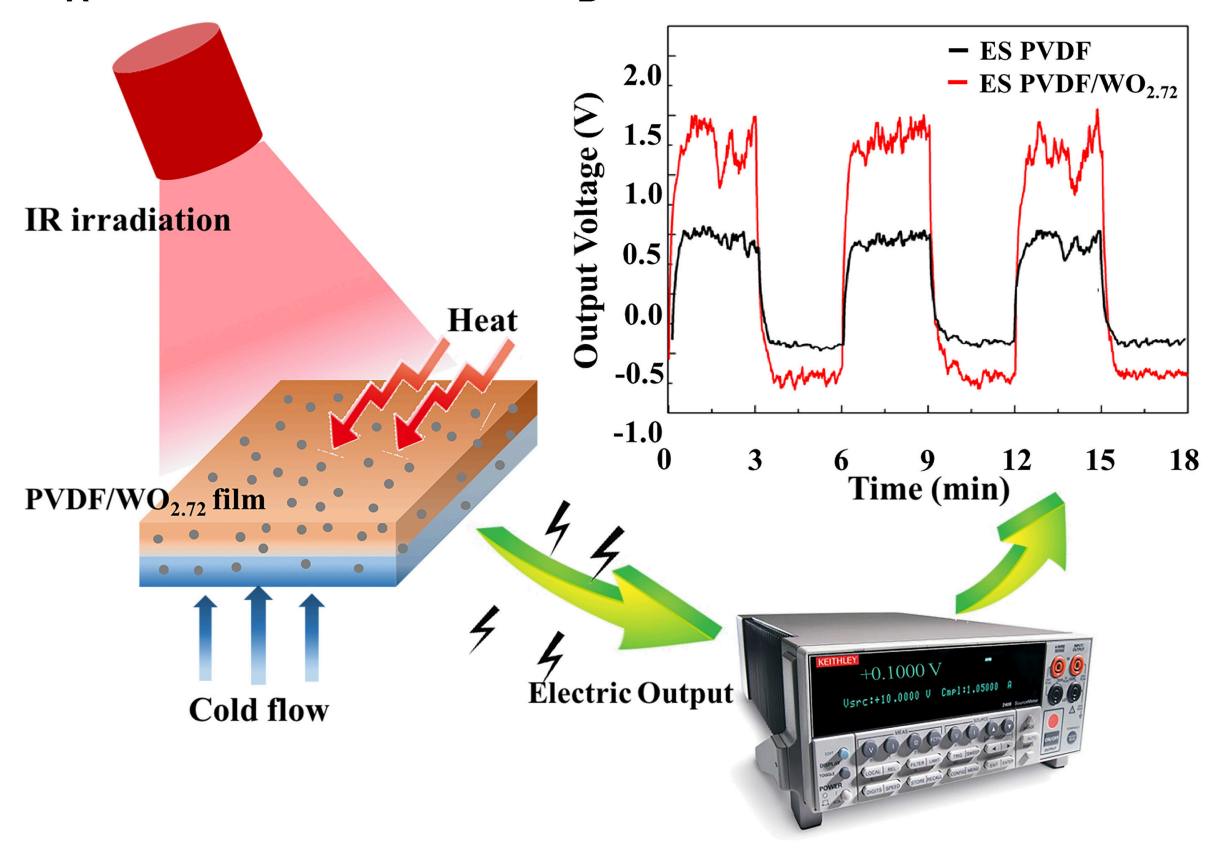

FIGURE 3 | (A) Schematic illustrations of the pyroelectric measurement and (B) pyroelectric ability of electrospun $\mathrm{PVDF}$ and $\mathrm{PVDF} / \mathrm{WO}_{2.72}$ in response to the corresponding rate of change in temperature (Wu et al., 2017a).

positive than the standard redox potential of $\mathrm{H}_{2} \mathrm{O} / \mathrm{O}_{2}(1.23 \mathrm{eV})$. The $\mathrm{VB}$ potential of $\mathrm{WO}_{3-\mathrm{x}}$ is located at ca. $3.0 \mathrm{eV}$, and thus is a promising material for water oxidation application (Wang et al., 2012; Yan et al., 2015).

\section{Reduction of $\mathrm{CO}_{2}$}

Photocatalytic reduction of $\mathrm{CO}_{2}$ is also a catalyst that is excited in order to generate electrons and holes, which migrate to the surface of the catalyst. Molecules adsorbed on the surface of the catalyst trigger a series of chemical reactions and eventually produce various products such as $\mathrm{CH}_{4}, \mathrm{HCOOH}, \mathrm{HCHO}$, and $\mathrm{CH}_{3} \mathrm{OH}$. However, the process of photoreduction of $\mathrm{CO}_{2}$ is complicated. In particular, the cleavage of $\mathrm{C}-\mathrm{O}$ bonds and the formation of $\mathrm{C}-\mathrm{H}$ bonds are complex processes. Xi reported that $\mathrm{WO}_{2.72}$ may also enable efficient reduction of $\mathrm{CO}_{2}$ to obtain $\mathrm{CH}_{4}$ (Xi et al., 2012).

\section{Hydrogen Production}

Photocatalysts may act as reducing and oxidizing agents. They may also decompose water molecules to produce $\mathrm{H}_{2}$ and $\mathrm{O}_{2}$. If photocatalysts are to be used to decompose water, their energy band gap (Eg) must be greater than $1.23 \mathrm{eV}(<1,000 \mathrm{~nm})$ and less than $3.0 \mathrm{eV}(>400 \mathrm{~nm})$ to respond in the visible region (Pihosh et al., 2015). In other words, the semiconductor photocatalyst must have a relatively small band gap $\left(1.23 \mathrm{eV}<\mathrm{E}_{\mathrm{g}}\right.$ $<3.0 \mathrm{eV}$ ) to absorb as much light as possible for the purpose of photogenerated electrons/holes (Zhang et al., 2018). The results of hydrogen production by photolysis showed that the hydrogen production efficiency of $\mathrm{g}-\mathrm{C}_{3} \mathrm{~N}_{4}$ improved considerably after $\mathrm{WO}_{2.72}$ was incorporated. The $\mathrm{WO}_{2.72}(30 \mathrm{wt} \%) / \mathrm{g}-\mathrm{C}_{3} \mathrm{~N}_{4}$ sample had the highest hydrogen production efficiency $(3.69 \mu \mathrm{mol}$ $\mathrm{h}^{-1}$ ), which was approximately 4.5 times that of pure $\mathrm{g}-\mathrm{C}_{3} \mathrm{~N}_{4}$ (Song et al., 2016).

\section{Degradation of Organic Compounds}

The conduction band of $\mathrm{WO}_{3}$ is slightly higher than the reduction potential of an $\mathrm{H}_{2} / \mathrm{H}_{2} \mathrm{O}$ reaction. In addition, its valence band is much higher than the oxidation potential of an $\mathrm{H}_{2} \mathrm{O} / \mathrm{O}_{2}$ reaction, which enables the $\mathrm{WO}_{3}$ photocatalytic oxidation degradation of many organic compounds such as textile dyes and bacteria contaminants. In addition, $\mathrm{WO}_{3}$ offers strong stability in an acidic environment, making it promising for treating wastewater that contains organic acids. The oxygen vacancies in $\mathrm{WO}_{3-\mathrm{x}}$ are helpful for $\mathrm{O}_{2}$ reduction because of the electron transfer between mixed-valence states. $\mathrm{WO}_{2.72}$ exhibits a higher activity than $\mathrm{WO}_{3}$ in pollutant degradation, and $\mathrm{O}_{2}{ }^{-}$is the major active species for the mineralization of pollutants (Bhuyan et al., 2017). Our research group recently reported on the outstanding photocatalytic activity of hybrid $\mathrm{Rb}_{\mathrm{x}} \mathrm{WO}_{3} / \mathrm{Ag}_{3} \mathrm{VO}_{4}$ degradation of methylene blue (MB) under a full spectrum (UV-VIS-NIR region). The photocatalytic performance was considerably enhanced because of the extended optical absorption in the entire UV-visible-NIR region, efficient separation of electron and hole pairs $(\mathrm{e}-/ \mathrm{h}+)$, and a synergetic effect between $\mathrm{Rb}_{\mathrm{x}} \mathrm{WO}_{3}$ and $\mathrm{Ag}_{3} \mathrm{VO}_{4}$ (Chala et al., 2018b).

\section{Oxidation of Alcohols}

The activated species in the photocatalytic reaction react with the alcohol, and the oxygen in the alcohol allows electrons to fill the holes in the valence band and finally obtain the 

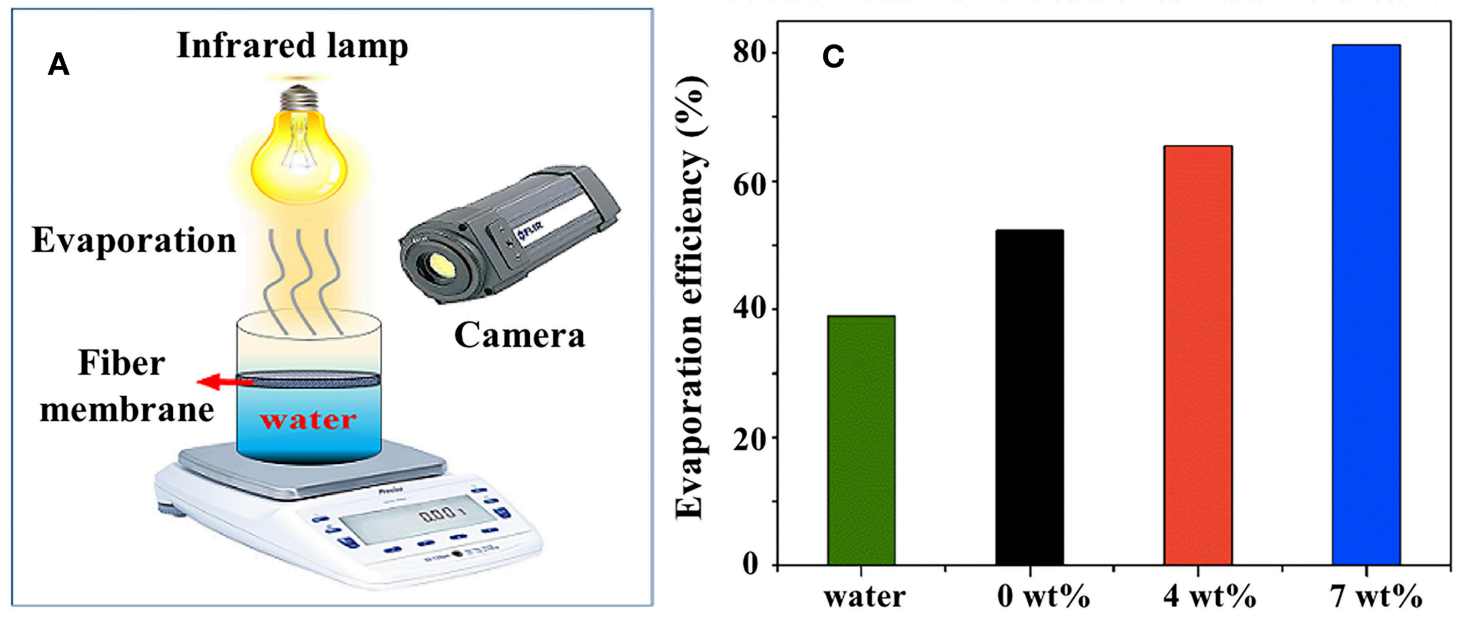

B

5 min irradiation

Sample
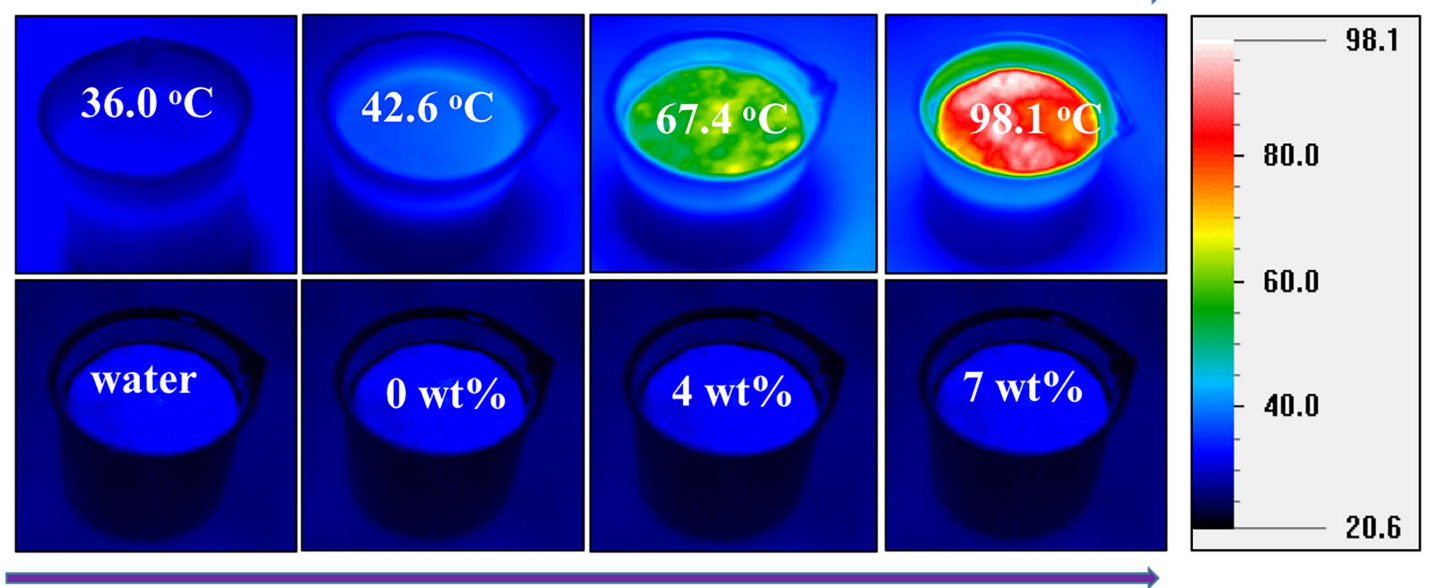

No irradiation

FIGURE 4 | (A) Schematic of water evaporation measurement with $\mathrm{WO}_{2.72} / \mathrm{PLA}$ fiber membrane floating on air-water interface, (B) temperature of WO $2.72 / P L A$ fiber membrane containing 0,4 , and $7 \mathrm{wt} \% \mathrm{WO}_{2.72}$ nanoparticles floating on water, and (C) evaporation efficiency for $\mathrm{WO}_{2.72} / \mathrm{PLA}$ fiber membrane containing 0,4 , and 7 wt\% $\mathrm{WO}_{2.72}$ nanoparticles. Reproduced with permission (Chala et al., 2018a). Copyright 2018, ACS.

corresponding aldehyde or ketone. The reaction has many advantages. For example, toxic and harmful metal salts do not need to be introduced as oxidants. In addition, it offers mild reaction conditions, minimal equipment requirements, a high conversion rate, and high selectivity. Thus, the photocatalytic oxidation of alcohols offers broad application prospects for the future. $\mathrm{WO}_{2.72}$ can be used for the photocatalytic dehydration of isopropanol to propylene (Bai et al., 2013). Three morphologies of $\mathrm{WO}_{2.72}$ including rods, urchins, and plates were studied. It was found that urchin-like products performed the best. $\mathrm{WO}_{3}$ and its hybrid have been widely explored for photocatalysis. Currently, hybrids of $\mathrm{WO}_{2.72}$ - or $\mathrm{M}_{\mathrm{x}} \mathrm{WO}_{3}$-based materials have received considerable attention for their use in developing solar absorbers capable of broadband absorption in the entire region. These materials must be further explored for photocatalysis.

\section{Energy-Related Applications}

$\mathrm{WO}_{3}$ and $\mathrm{WO}_{3-\mathrm{x}}$ have more efficient prospects for energy storage devices because of their multiple oxidation states, low price, high intrinsic density, high melting temperatures, and strong mechanical properties. These have been widely studied for supercapacitor electrodes, lithium ion batteries (LIB), and fuel cells. These are discussed in more detail as follows.

\section{Supercapacitors}

In the studies on supercapacitors, $\mathrm{WO}_{3}$ has been shown to suffer from low electrical conductivity because of the presence of oxides (Liu et al., 2018). Partial reduction of $\mathrm{WO}_{3-\mathrm{x}}$ enhanced the electrical conductivity because of multiple oxidation states $\left(\mathrm{W}^{+5}\right.$ and $\left.\mathrm{W}^{+6}\right)$. It was found to have high capacity and faster performance than other tungsten oxides. Yoon et al. (2011b) synthesized mesoporous $\mathrm{WO}_{3-\mathrm{x}}\left(\mathrm{m}-\mathrm{WO}_{3-\mathrm{x}}\right)$ and 


\section{A}

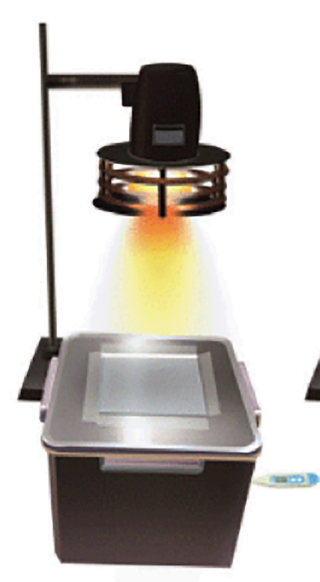

Quartz glass

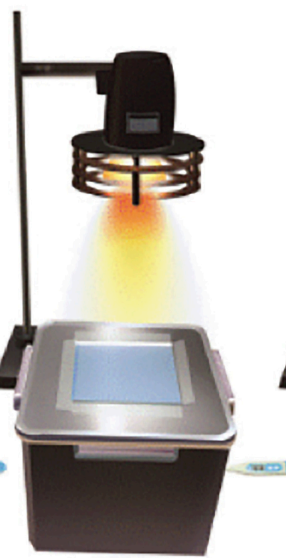

$\mathrm{Cs}_{x} \mathrm{WO}_{3} / \mathrm{ZnO}$ coated quartz glass

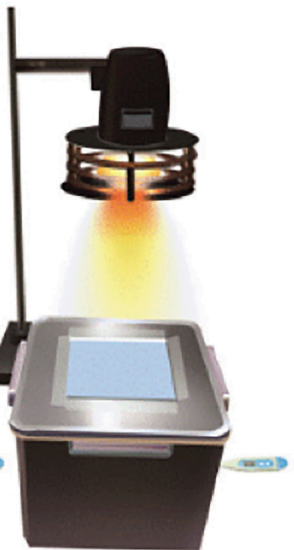

ITO coated quartz glass

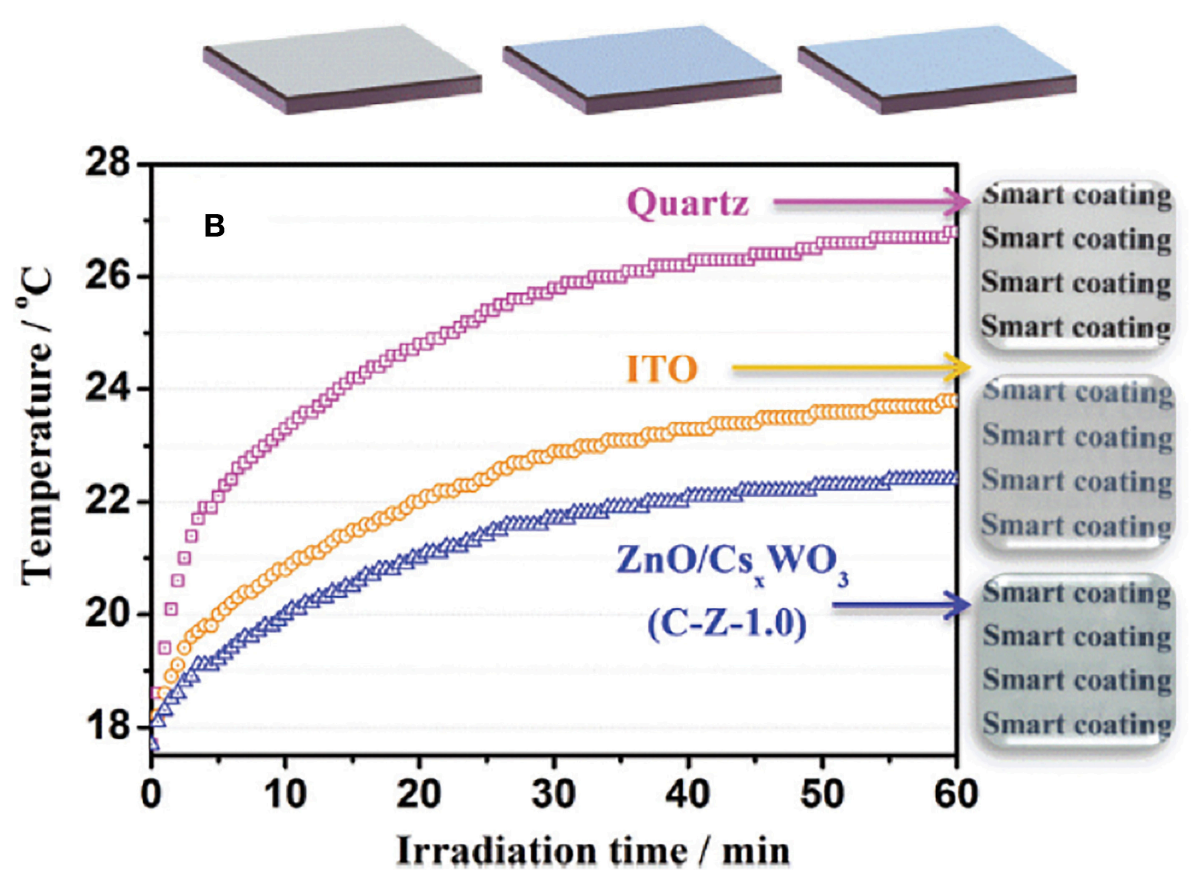

FIGURE 5 | (A) Schematic illustration of the simulated heat ray shielding test using the boxes with facet covered by pure quartz glass, WO $\mathrm{W}_{2.72}$ nanorods coated on quartz glass and ITO glass under the irradiation of a $50 \mathrm{~W}$ halogen lamp, and the temperature changes were determined by an electronic thermometer. (B) Time dependence of the temperature in the box. Reproduced with permission (Guo et al., 2012c) Copyright 2012, ACS.

found it had high rate capability and excellent capacitance of $366 \mathrm{\mu Fcm}^{-2}$ and $639 \mathrm{Fcm}^{-3}$, respectively. Ordered mesoporous $\mathrm{WO}_{3-\mathrm{x}}$ showed high electrical conductivity of $1.76 \mathrm{~S} \mathrm{~cm}^{-1}$ and highly interconnected ordered pores with a large surface area, making them suitable for use in electrode materials of supercapacitors (Zhou et al., 2013). explored ordered mesoporous carbon $/ \mathrm{WO}_{3-\mathrm{x}}$ nanocomposites. The results revealed excellent rate capability with high volumetric capacity $\left(125 \mathrm{Fcm}^{-1}\right.$ ) (Tian et al., 2014). developed a novel smart supercapacitor electrode engraved with a pattern consisting of $\mathrm{WO}_{2.72}$ on a PANI background. Both $\mathrm{WO}_{2.72}$ and PANI displayed multiple color changes and they operated electrochemically with a widened potential window. The specific capacitance was found to be $302 \mathrm{Fg}^{-1}$ at $10 \mathrm{Ag}^{-1}$ current density, which might appear as a new feature of supercapacitors. Among the various $\mathrm{WO}_{\mathrm{x}^{\prime} \mathrm{s}}, \mathrm{WO}_{2.72}$ has attracted the most interest because it offers the highest oxygen deficiencies. Moreover, it is the most stable form and possesses good conductivity, making it a promising candidate for supercapacitors (Jung and Kim, 2018; Huang et al., 2019; Li et al., 2019a). 


\section{Lithium-Ion Batteries (LIB)}

$\mathrm{WO}_{3}$ has been used as an anode material because it offers a high theoretical capacity, low cost, and environmental friendliness. The only major drawback is its low electrical conductivity, although this has been improved with $\mathrm{WO}_{3-\mathrm{x}}$ materials. Yoon et al. (2011a) focused on developing high performance anode mesoporous $\mathrm{WO}_{3-\mathrm{x}}$ using a hard template with high electrical conductivity. The developed material exhibited a high reversible capacity (748 $\mathrm{mAh}^{-1}$ ) and a high volumetric capacity (1,500 $\mathrm{mAh} \mathrm{cm}^{-3}$ ) compared to the bulk $\mathrm{WO}_{3-\mathrm{x}}$. Lee et al. (2014a) reported that flexible reduced tungsten oxide-carbon composite nanofiber $\left(\mathrm{WO}_{\mathrm{x}}-\mathrm{C}-\mathrm{NF}\right)$ films used as anode materials in LIB exhibited a high reversible capacity $\left(481 \mathrm{~mA} \mathrm{~h} \mathrm{~g}^{-1}\right)$, stable cycle, and improved rate performance compared to $\mathrm{WO}_{\mathrm{x}}-\mathrm{C}$ nano and $\mathrm{WO}_{\mathrm{x}}$-nano electrodes. These studies proved that $\mathrm{WO}_{3-\mathrm{x}}$ is one of the most promising anode materials for LIB. Recently, $\mathrm{WO}_{3-\mathrm{x}}$ composites as anode materials for high performance lithium-ion batteries were reported (Zhang et al., 2015b; Yue et al., 2017; Li et al., 2019b). Liu et al. (2017) reported that flower-like $\mathrm{WO}_{3} / \mathrm{CoWO}_{4} / \mathrm{Co}$ nanostructure electrodes could deliver discharge capacities of 2,435 and 1,074 $\mathrm{mAhg}^{-1}$ during the first cycle at current densities of 100 and $200 \mathrm{mAg}^{-1}$ respectively. The pristine $\mathrm{WO}_{3}$ electrode without cobalt doping exhibited a capacity of 1,151 and $331 \mathrm{mAhg}^{-1}$ at 100 and $200 \mathrm{mAg}^{-1}$ respectively. The hybrids of $\mathrm{WO}_{3}$ (i.e., $\mathrm{WO}_{3} / \mathrm{CoWO}_{4} / \mathrm{Co}$ composites used as anode materials) have superior cycling performance as compared to that of $\mathrm{WO}_{3}$ particles.

\section{Fuel Cells}

$\mathrm{H}_{2}$ fuel has been investigated extensively. Improved catalytic activity and durability are highly desirable for this technology. Here, we focus on the use of $\mathrm{WO}_{3-\mathrm{x}}$-based electrocatalysts in fuel cells. Lu et al. (2014) synthesized Pd tetrahedrontungsten oxide nanosheet hybrids $\left(\mathrm{Pd} / \mathrm{WO}_{2.72}\right)$ that enhanced electrocatalytic activity and provided durability for fuel cells. As compared to $\mathrm{Pd}$ nanocrystal, $\mathrm{Pd} / \mathrm{WO}_{2.72}$ hybrids demonstrated not only high activity but also superior stability for the oxygen reduction reaction (ORR) in alkaline solutions. The mass activity of $\mathrm{Pd} / \mathrm{WO}_{2.72}$ at $0.90 \mathrm{~V}$ is $0.216 \mathrm{~A} \mathrm{mg}^{-1}$, which is much higher than commercial Pt/C, Pd NPs, and Pd/C. Kang et al. (2010) prepared ordered mesoporous $\mathrm{WO}_{3-\mathrm{x}}$ by using a hard template and mesostructured $\mathrm{WO}_{3-\mathrm{x}}$ responsible for its high conductivity. $\mathrm{Pt} /$ mesoporous $\mathrm{WO}_{3-\mathrm{x}}$ exhibited a considerable tolerance to cycling between 0.6 and $1.3 \mathrm{~V}_{\mathrm{NHE}}$. It could be used as an ORR catalyst support, thus offering long-term stability. In general, hybrids of $\mathrm{WO}_{3}$ have been explored widely for energy-related devices in the past few decades. Hybrids of $\mathrm{WO}_{2.72}$ in energy applications have also gained attention recently, but $\mathrm{M}_{\mathrm{X}} \mathrm{WO}_{3}$ remain unnoticed.

\section{Gas Sensors}

$\mathrm{WO}_{\mathrm{x}}$ has oxygen defects in its crystal lattice, which cause the band to bend and enable conductivity. When the material is in contact with oxygen, oxygen absorbs electrons from the surface of the semiconductor to form negative ions, and the surface energy band is bent upward. This results in a decrease in surface electron concentration of the gas sensing material, a decrease in electrical conductivity, and an increase in resistance of the sensor. However, if the gas sensitive material is in contact with the reducing gas, desorption occurs, the surface energy band is lowered, both the electron concentration and electrical conductivity increase, and the resistance value of the sensor decreases.

$\mathrm{WO}_{3}$ and $\mathrm{WO}_{2.72}$ were reported as sensor materials to monitor flammable and toxic gases such as $\mathrm{NH}_{3}$ (Kim et al., 2005), $\mathrm{NO}_{\mathrm{x}}$ (Qin et al., 2011a), $\mathrm{H}_{2}$ (Boudiba et al., 2010), $\mathrm{H}_{2} \mathrm{~S}$ (Rout et al., 2008), and $\mathrm{SO}_{\mathbf{x}}$ (Godbole et al., 2017). $\mathrm{WO}_{\mathbf{x}}$ can also reduce gases such as $\mathrm{H}_{2}, \mathrm{CH}_{4}, \mathrm{CO}_{\mathrm{x}}$ (Stankova et al., 2005), and $\mathrm{C}_{2} \mathrm{H}_{5} \mathrm{OH}$ (Vallejos et al., 2015). Although $\mathrm{WO}_{2.72}$ has the largest oxygen deficiency, it has greater potential in this field (Wang et al., 2018). prepared $\mathrm{WO}_{3}$ nanorod/sulfonated reduced graphene oxides $\left(\mathrm{WO}_{3} / \mathrm{S}-\mathrm{rGO}\right)$, which showed fast response recovery characteristics at all concentrations of $\mathrm{NO}_{2}$ gas, indicating its good response and recovery properties for sensor applications. However, the gas sensor of the $\mathrm{WO}_{\mathrm{x}}$ still has the disadvantages of poor stability, low selectivity, and a high operating temperature. Therefore, how to reduce the working temperature and improve the selectivity and sensitivity of the detection gas have become the focus of our current research. Composite and metal-hybrid doping have proven effective at improving the sensitivity of $\mathrm{WO}_{\mathrm{x}}$ for reducing gases. $\mathrm{WO}_{3}$ and its hybrid are widely explored for gas sensors and the properties of $\mathrm{WO}_{2.72}$ have recently gained attention. However, $\mathrm{M}_{\mathrm{x}} \mathrm{WO}_{3}$ has yet to be fully studied.

\section{CONCLUSION AND FUTURE PROSPECTS}

In this study, we summarized the comprehensive progress made in the last few years in the application of tungstenoxide-based materials. $\mathrm{WO}_{3-\mathrm{x}}, \mathrm{M}_{\mathrm{x}} \mathrm{WO}_{3}$, and their hybrid materials as interesting research topics, particularly for morphology control and composite construction to enhance optical absorption, charge separation, redox capability, and electrical conductivity. The well-studied liquid-phase technique known as the solvothermal treatment is the most used method alongside the hydrothermal treatment, which is a facile and cost-effective method that can produce WOx with different nanomorphologies. The morphology can be fine-tuned by controlling variables such as time, precursor concentration, and temperature. A critical challenge is to enhance the utilization efficiency by extending the solar spectrum response from the UV to the NIR region. To meet these requirements, hybrids of $\mathrm{WO}_{2.72}$ and $\mathrm{M}_{\mathrm{X}} \mathrm{WO}_{3}$ have become important because of their strong photoabsorption ability and intervalence charge properties. A major advantage of this material is the LSPR effect, which may encourage researchers to focus not only on the interesting properties for new applications but also to investigate the many opportunities it offers to improve the efficiency of current applications.

\section{DATA AVAILABILITY}

All datasets generated for this study are included in the manuscript and/or the supplementary files. 


\section{AUTHOR CONTRIBUTIONS}

C-MW performed initial literature search to identify papers, provided relevant information for the text, reviewed final manuscript, and conceptualization. SN contributed to writing the manuscript. M-HC, J-HW, and Y-QJ performed literature search and provided relevant information. All authors approved the final version to be

\section{REFERENCES}

Aoki, T., Matsushita, T., Suzuki, A., Tanabe, K., and Okuda, M. (2005). Optical recording characteristics of $\mathrm{WO}_{3}$ films grown by pulsed laser deposition method. J. Vacuum Sci. Technol. A 23, 1325-1330. doi: 10.1116/1.1978891

Awad, F.S., Kiriarachchi, H.D., Abouzeid, K.M., özgürü., and El-Shall, M.S. (2018). Plasmonic graphene polyurethane nanocomposites for efficient solar water desalination. ACS Appl. Energy Mater. 1, 976-985. doi: 10.1021/acsaem.8b00109

Baek, Y., and Yong, K. (2007). Controlled growth and characterization of tungsten oxide nanowires using thermal evaporation of $\mathrm{WO}_{3}$ powder. J. Phys. Chem. C 111, 1213-1218. doi: 10.1021/jp0659857

Bai, H., Su, N., Li, W., Zhang, X., Yan, Y., Li, P., et al. (2013). $\mathrm{W}_{18} \mathrm{O}_{49}$ nanowire networks for catalyzed dehydration of isopropyl alcohol to propylene under visible light. J. Mater. Chem. A 1, 6125-6129. doi: 10.1039/c3ta10835j

Bhuyan, B., Paul, B., Dhar, S.S., and Vadivel, S. (2017). Facile hydrothermal synthesis of ultrasmall $\mathrm{W}_{18} \mathrm{O}_{49}$ nanoparticles and studies of their photocatalytic activity towards degradation of methylene blue. Mater. Chem. Phys. 188, 1-7. doi: 10.1016/j.matchemphys.2016.12.035

Boudiba, A., Zhang, C., Navio, C., Bittencourt, C., Snyders, R., and Debliquy, M. (2010). Preparation of highly selective, sensitive and stable hydrogen sensors based on Pd-doped tungsten trioxide. Proc. Eng. 5, 180-183. doi: 10.1016/j.proeng.2010.09.077

Chala, T. F., Wu, C.-M., Chou, M.-H., Gebeyehu, M. B., and Cheng, K.-B. (2017). Highly efficient near infrared photothermal conversion properties of reduced tungsten oxide/polyurethane nanocomposites. Nanomaterials 7:91. doi: 10.3390/nano7070191

Chala, T. F., Wu, C.-M., Chou, M.-H., and Guo, Z.-L. (2018a). Melt electrospun reduced tungsten oxide/polylactic acid fiber membranes as a photothermal material for light-driven interfacial water evaporation. ACS Appl. Mater. Interfaces 10, 28955-28962. doi: 10.1021/ acsami.8b07434

Chala, T. F., Wu, C.-M., and Motora, K. G. (2018b). RbxWO3/Ag3VO4 Nanocomposites Towards Efficient Full-Spectrum (UV, Visible, and Near Infrared) Photocatalysis (Taiwan Institute of Chemical Engineers).

Chen, C.-J., and Chen, D.-H. (2013). Preparation and near-infrared photothermal conversion property of cesium tungsten oxide nanoparticles. Nanoscale Res. Lett. 8, 57. doi: 10.1186/1556-276X-8-57

Chen, J., Wang, D., Xi, J., Au, L., Siekkinen, A., Warsen, A., et al. (2007). Immuno gold nanocages with tailored optical properties for targeted photothermal destruction of cancer cells. Nano Lett. 7, 1318-1322. doi: 10.1021/nl070345g

Chen, Q., Pei, Z., Xu, Y., Li, Z., Yang, Y., Wei, Y., et al. (2018). A durable monolithic polymer foam for efficient solar steam generation. Chem. Sci. 9, 623-628. doi: 10.1039/C7SC02967E

Chen, Z., Wang, Q., Wang, H., Zhang, L., Song, G., Song, L., et al. (2013). Ultrathin PEGylated $\mathrm{W}_{18} \mathrm{O}_{49}$ nanowires as a new 980 nm-laser-driven photothermal agent for efficient ablation of cancer cells in vivo. Adv. Mater. 25, 2095-2100. doi: $10.1002 /$ adma.201204616

Ding, D., Huang, W., Song, C., Yan, M., Guo, C., and Liu, S. (2017). Nonstoichiometric $\mathrm{MoO}_{3-\mathrm{x}}$ quantum dots as a light-harvesting material for interfacial water evaporation. Chem. Commun. 53, 6744-6747. doi: 10.1039/C7CC01427A

Godbole, R., Godbole, V. P., and Bhagwat, S. (2017). Surface morphology dependent tungsten oxide thin films as toxic gas sensor. Mater. Sci. Semicond. Process. 63, 212-219. doi: 10.1016/j.mssp.2017.02.023 published and agreed to be accountable for all aspects of the work.

\section{ACKNOWLEDGMENTS}

The authors are thankful for the partial financial support received from the Ministry of Science and Technology of Taiwan, ROC, under contract numbers: MOST 107-2221-E-011-044.

Guo, C., Yin, S., Dong, Q., and Sato, T. (2012a). Simple route to $\left(\mathrm{NH}_{4}\right)_{\mathrm{X}} \mathrm{WO}_{3}$ nanorods for near infrared absorption. Nanoscale 4, 3394-3398. doi: $10.1039 / \mathrm{c} 2 \mathrm{nr} 30612 \mathrm{c}$

Guo, C., Yin, S., Huang, L., and Sato, T. (2011a). Synthesis of one-dimensional potassium tungsten bronze with excellent near-infrared absorption property. ACS Appl. Mater. Interfaces 3, 2794-2799. doi: 10.1021/am200631e

Guo, C., Yin, S., Huang, Y., Dong, Q., and Sato, T. (2011b). Synthesis of $\mathrm{W}_{18} \mathrm{O}_{49}$ nanorod via ammonium tungsten oxide and its interesting optical properties. Langmuir 27, 12172-12178. doi: 10.1021/la202513q

Guo, C., Yin, S., and Sato, T. (2012b). Tungsten oxide-based nanomaterials: morphological-control, properties, and novel applications. Rev. Adv. Sci. Eng. 1, 235-263. doi: 10.1166/rase.2012.1016

Guo, C., Yin, S., Yan, M., Kobayashi, M., Kakihana, M., and Sato, T. (2012c). Morphology-controlled synthesis of $\mathrm{W}_{18} \mathrm{O}_{49}$ nanostructures and their near-infrared absorption properties. Inorg. Chem. 51, 4763-4771. doi: $10.1021 /$ ic $300049 j$

Guo, C., Yin, S., Zhang, P., Yan, M., Adachi, K., Chonan, T., et al. (2010). Novel synthesis of homogenous $\mathrm{Cs}_{\mathrm{X}} \mathrm{WO}_{3}$ nanorods with excellent NIR shielding properties by a water controlled-release solvothermal process. J. Mater. Chem. 20, 8227-8229. doi: 10.1039/c0jm01972k

Guo, X., Qin, X., Xue, Z., Zhang, C., Sun, X., Hou, J., et al. (2016). Morphologycontrolled synthesis of $\mathrm{WO}_{2.72}$ nanostructures and their photocatalytic properties. RSC Adv. 6, 48537-48542. doi: 10.1039/C6RA08551B

Hashishin, T., and Tamaki, J. (2008). Conductivity-type sensor based on CNT-WO3 composite for NO2 detection. J. Nanomater. 2008:31. doi: $10.1155 / 2008 / 352854$

Hu, X., Xu, W., Zhou, L., Tan, Y., Wang, Y., Zhu, S., et al. (2017). Tailoring graphene oxide-based aerogels for efficient solar steam generation under one sun. Adv. Mater. 29:1604031. doi: 10.1002/adma.201604031

Hu, X.-S., Shen, Y., Xu, L.-H., Wang, L.-M., Lu, L.-S., and Zhang, Y.-T. (2016). Preparation of flower-like CuS by solvothermal method for photocatalytic, UV protection and EMI shielding applications. Appl. Surf. Sci. 385, 162-170. doi: 10.1016/j.apsusc.2016.05.089

Hua, Z., Li, B., Li, L., Yin, X., Chen, K., and Wang, W. (2017). Designing a novel photothermal material of hierarchical microstructured copper phosphate for solar evaporation enhancement. J. Phys. Chem. C 121, 60-69. doi: $10.1021 /$ acs.jpcc.6b08975

Huang, S., He, Q., Xu, S., and Wang, L. (2015a). Polyaniline-based photothermal paper sensor for sensitive and selective detection of 2,4,6-trinitrotoluene. Anal. Chem. 87, 5451-5456. doi: 10.1021/acs.analchem.5b01078

Huang, W., and El-Sayed, M.A. (2008). Photothermally excited coherent lattice phonon oscillations in plasmonic nanoparticles. Eur. Phys. J.Spec. Top. 153, 325-333. doi: 10.1140/epjst/e2008-00456-x

Huang, X., and El-Sayed, M.A. (2010). Gold nanoparticles: optical properties and implementations in cancer diagnosis and photothermal therapy. J. Adv. Res. 1, 13-28. doi: 10.1016/j.jare.2010.02.002

Huang, X., Zhang, Z., Li, H., Wang, H., and Ma, T. (2019). In-situ growth of nanowire $\mathrm{WO}_{2.72}$ on carbon cloth as a binder-free electrode for flexible asymmetric supercapacitors with high performance. J. Energy Chem. 29, 58-64. doi: 10.1016/j.jechem.2018.01.024

Huang, Z.-F., Song, J., Pan, L., Jia, X., Li, Z., Zou, J.-J., et al. (2014a). $\mathrm{W}_{18} \mathrm{O}_{49}$ nanowire alignments with a $\mathrm{BiOCl}$ shell as an efficient photocatalyst. Nanoscale 6, 8865-8872. doi: 10.1039/C4NR00905C

Huang, Z.-F., Song, J., Pan, L., Lv, F., Wang, Q., Zou, J.-J., et al. (2014b). Mesoporous $\mathrm{W}_{18} \mathrm{O}_{49}$ hollow spheres as highly active 
photocatalysts. Chem. Commun. 50, 10959-10962. doi: 10.1039/C4CC0 $2201 \mathrm{G}$

Huang, Z.-F., Song, J., Pan, L., Zhang, X., Wang, L., and Zou, J.-J. (2015b). Tungsten oxides for photocatalysis, electrochemistry, and phototherapy. $A d v$. Mater. 27, 5309-5327. doi: 10.1002/adma.201501217

Huiyuan, L., Hua, L., Yujie, C., and Hezhou, L. (2018). A facile hydrothermal method to synthesize ammonium tungsten bronze nanoplatelets for nir absorption. IOP Conf. Series Mater. Sci. Eng. 382:022062. doi: 10.1088/1757-899X/382/2/022062

Hussain, A., Gruehn, R., and Rüscher, C.H. (1997). Crystal growth of alkali metal tungsten brozes $\mathrm{M}_{\mathrm{x}} \mathrm{WO}_{3}(\mathrm{M}=\mathrm{K}, \mathrm{Rb}, \mathrm{Cs})$, and their optical properties. J. Alloys Compd. 246, 51-61. doi: 10.1016/S0925-8388(96)02470-X

Jiang, Q., Gholami Derami, H., Ghim, D., Cao, S., Jun, Y.-S., and Singamaneni, S. (2017). Polydopamine-filled bacterial nanocellulose as a biodegradable interfacial photothermal evaporator for highly efficient solar steam generation. J. Mater. Chem. A 5, 18397-18402. doi: 10.1039/C7TA04834C

Jin, Y.Z., Zhu, Y.Q., Whitby, R.L., Yao, N., Ma, R., Watts, P.C., et al. (2004). Simple approaches to quality large-scale tungsten oxide nanoneedles. J. Phys. Chem. B 108, 15572-15577. doi: 10.1021/jp048596q

Jung, J., and Kim, D.H. (2018). $\mathrm{W}_{18} \mathrm{O}_{49}$ nanowires assembled on carbon felt for application to supercapacitors. Appl. Surf. Sci. 433, 750-755. doi: 10.1016/j.apsusc.2017.10.109

Kang, E., An, S., Yoon, S., Kim, J.K., and Lee, J. (2010). Ordered mesoporous $\mathrm{WO}_{3-\mathrm{x}}$ possessing electronically conductive framework comparable to carbon framework toward long-term stable cathode supports for fuel cells. J. Mater. Chem. 20, 7416-7421. doi: 10.1039/c0jm00227e

Kim, J. Y., Jeong, S. Y., Shin, G. J., Lee, S. K., and Choi, K. H. (2012). Near infrared cut-off characteristics of various perovskitebased composite films. Appl. Mech. Mater. 229-231, 2733-2736. doi: 10.4028/www.scientific.net/AMM.229-231.2733

Kim, K., Yu, S., An, C., Kim, S.-W., and Jang, J.-H. (2018). Mesoporous three-dimensional graphene networks for highly efficient solar desalination under 1 sun illumination. ACS Appl. Mater. Interfaces 10, 15602-15608. doi: 10.1021/acsami.7b19584

Kim, Y. S., Ha, S.-C., Kim, K., Yang, H., Choi, S.-Y., Kim, Y.T., et al. (2005). Roomtemperature semiconductor gas sensor based on non-stoichiometric tungsten oxide nanorod film. Appl. Phys. Lett. 86:213105. doi: 10.1063/1.1929872

Late, D. J., Kashid, R. V., Sekhar rout, C., More, M. A., and Joag, D. S. (2010). Low threshold field electron emission from solvothermally synthesized WO2.72 nanowires. Appl. Phys. A 98, 751-756. doi: 10.1007/s00339-009-5536-0

Lee, J., Jo, C., Park, B., Hwang, W., Lee, H.I., Yoon, S., et al. (2014a). Simple fabrication of flexible electrodes with high metal-oxide content: electrospun reduced tungsten oxide/carbon nanofibers for lithium ion battery applications. Nanoscale 6, 10147-10155. doi: 10.1039/C4NR01033G

Lee, K., Seo, W.S., and Park, J.T. (2003). Synthesis and Optical properties of colloidal tungsten oxide nanorods. J. Am. Chem. Soc. 125, 3408-3409. doi: $10.1021 / j a 034011 \mathrm{e}$

Lee, S. Y., Kim, J. Y., Lee, J. Y., Song, H. J., Lee, S., Choi, K. H., et al. (2014b). Facile fabrication of high-efficiency near-infrared absorption film with tungsten bronze nanoparticle dense layer. Nanoscale Res. Lett. 9:294. doi: 10.1186/1556-276X-9-294

Li, B., Shao, X., Liu, T., Shao, L., and Zhang, B. (2016a). Construction of metal/ $\mathrm{WO}_{2.72} / \mathrm{rGO}$ ternary nanocomposites with optimized adsorption, photocatalytic and photoelectrochemical properties. Appl. Catal. B Environ. 198, 325-333. doi: 10.1016/j.apcatb.2016.06.001

Li, G., Gao, L., Li, L., and Guo, L. (2019a). An electrochromic and self-healing multi-functional supercapacitor based on PANI/nw-WO2.7/Au NPs electrode and hydrogel electrolyte. J. Alloys Comp. 786, 40-49. doi: 10.1016/j.jallcom.2018.12.142

Li, G., Wu, G., Guo, C., and Wang, B. (2016b). Fabrication of one-dimensional $\mathrm{W}_{18} \mathrm{O}_{49}$ nanomaterial for the near infrared shielding. Mater. Lett. 169, 227-230. doi: 10.1016/j.matlet.2016.01.094

Li, G., Zhang, S., Guo, C., and Liu, S. (2016c). Absorption and electrochromic modulation of near-infrared light: realized by tungsten suboxide. Nanoscale 8 , 9861-9868. doi: 10.1039/C5NR09147K

Li, Y., Chang, K., Tang, H., Li, B., Qin, Y., Hou, Y., et al. (2019b). Preparation of oxygen-deficient $\mathrm{WO}_{3-\mathrm{x}}$ nanosheets and their characterization as anode materials for high-performance Li-ion batteries. Electrochim. Acta 298, 640649. doi: 10.1016/j.electacta.2018.12.137

Liao, C.-C., Chen, F.-R., and Kai, J.-J. (2007). Electrochromic properties of nanocomposite $\mathrm{WO}_{3}$ films. Solar Energy Mater. Solar Cells 91, 1282-1288. doi: 10.1016/j.solmat.2006.11.020

Lin, H., Wang, X., Yu, L., Chen, Y., and Shi, J. (2017). Two-dimensional ultrathin Mxene ceramic nanosheets for photothermal conversion. Nano Lett. 17, 384391. doi: 10.1021/acs.nanolett.6b04339

Liu, G., Wang, S., Nie, Y., Sun, X., Zhang, Y., and Tang, Y. (2013a). Electrostatic-induced synthesis of tungsten bronze nanostructures with excellent photo-to-thermal conversion behavior. J. Mater. Chem. A 1, 1012010129. doi: 10.1039/c3ta11479a

Liu, J., Zhang, Z., Wang, Z., Tang, M., Li, J., Yi, J., et al. (2017). Flowerlike $\mathrm{WO}_{3} / \mathrm{CoWO}_{4} / \mathrm{Co}$ nanostructures as high performance anode for lithium ion batteries. J. Alloys Compd. 727, 107-113. doi: 10.1016/j.jallcom.2017. 08.057

Liu, J.-X., Ando, Y., Dong, X.-L., Shi, F., Yin, S., Adachi, K., et al. (2010). Microstructure and electrical-optical properties of cesium tungsten oxides synthesized by solvothermal reaction followed by ammonia annealing. J. Solid State Chem. 183, 2456-2460. doi: 10.1016/j.jssc.2010.08.017

Liu, X., He, Y., Wang, S., Zhang, Q., and Song, M. (2012). Controllable synthesis and tunable field-emission properties of tungsten oxide sub-micro fibers. Int. J. Refract. Metals Hard Mater. 34, 47-52. doi: 10.1016/j.ijrmhm. 2012.04.002

Liu, X., Sheng, G., Zhong, M., and Zhou, X. (2018). Dispersed and size-selected $\mathrm{WO}_{3}$ nanoparticles in carbon aerogel for supercapacitor applications. Mater. Des. 141, 220-229. doi: 10.1016/j.matdes.2017.12.038

Liu, X., Song, M., Wang, S., and He, Y. (2013b). Structure and field-emission properties of $\mathrm{W} / \mathrm{WO}_{2.72}$ heterostructures fabricated by vapor deposition. Phys. E 53, 260-265. doi: 10.1016/j.physe.2013.05.017

Liu, Y., Chen, J., Guo, D., Cao, M., and Jiang, L. (2015). Floatable, self-cleaning, and carbon-black-based superhydrophobic gauze for the solar evaporation enhancement at the air-water interface. ACS Appl. Mater. Interfaces 7, 1364513652. doi: 10.1021/acsami.5b03435

Lou, J., Liu, Y., Wang, Z., Zhao, D., Song, C., Wu, J., et al. (2016). Bioinspired multifunctional paper-based rGO composites for solar-driven clean water generation. ACS Appl. Mater. Interfaces 8, 14628-14636. doi: 10.1021/acsami.6b04606

Lou, X. W., and Zeng, H. C. (2003). An inorganic route for controlled synthesis of $\mathrm{W}_{18} \mathrm{O}_{49}$ nanorods and nanofibers in solution. Inorg. Chem. 42, 6169-6171. doi: 10.1021/ic034771q

Lu, Y., Jiang, Y., Gao, X., Wang, X., and Chen, W. (2014). Strongly coupled Pd nanotetrahedron/tungsten oxide nanosheet hybrids with enhanced catalytic activity and stability as oxygen reduction electrocatalysts. J. Am. Chem. Soc. 136, 11687-11697. doi: 10.1021/ja5041094

Ma, B., Huang, E., Wu, G., Dai, W., Guan, N., and Li, L. (2017). Fabrication of $\mathrm{WO}_{2.72}$ /RGO nano-composites for enhanced photocatalysis. RSC Adv. 7, 2606-2614. doi: 10.1039/C6RA26416F

Mamak, M., Choi, S.Y., Stadler, U., Dolbec, R., Boulos, M., and Petrov, S. (2010). Thermal plasma synthesis of tungsten bronze nanoparticles for near infra-red absorption applications. J. Mater. Chem. 20, 9855-9857. doi: $10.1039 / \mathrm{c} 0 \mathrm{jm} 02169 \mathrm{e}$

Marques, M. P. M. (2013). Platinum and palladium polyamine complexes as anticancer agents: the structural factor. ISRN Spectrosc. 2013, 1-29. doi: $10.1155 / 2013 / 287353$

Ming, X., Guo, A., Wang, G., and Wang, X. (2018). Two-dimensional defective tungsten oxide nanosheets as high performance photo-absorbers for efficient solar steam generation. Solar Energy Mater. Solar Cells 185, 333-341. doi: 10.1016/j.solmat.2018.05.049

Moon, K., Cho, J.-J., Lee, Y.-B., Yoo, P. J., Bark, C. W., and Park, J. (2013). Near infrared shielding properties of quaternary tungsten bronze nanoparticle $\mathrm{Na}_{0.11} \mathrm{Cs}_{0.22} \mathrm{WO}_{3}$. Bull. Korean Chem. Soc. 34, 731-734. doi: $10.5012 /$ bkcs.2013.34.3.731

Moshofsky, B., and Mokari, T. (2012). Length and diameter control of ultrathin nanowires of substoichiometric tungsten oxide with insights into the growth mechanism. Chem. Mater. 25, 1384-1391. doi: 10.1021/cm30 $2015 z$ 
Okusako, T., Tokuyama, T., Mikami, K., Nogami, Y., and Hanasaki, N. (2012). Thermoelectric effect in hexagonal tungsten oxides. J. Phys. Soc. Japan 81:SB028. doi: 10.1143/JPSJS.81SB.SB028

Pihosh, Y., Turkevych, I., Mawatari, K., Uemura, J., Kazoe, Y., Kosar, S., et al. (2015). Photocatalytic generation of hydrogen by core-shell $\mathrm{WO}_{3} / \mathrm{BiVO}_{4}$ nanorods with ultimate water splitting efficiency. Sci. Rep. 5:11141. doi: 10.1038/srep11141

Qin, Y., Li, X., Wang, F., and Hu, M. (2011a). Solvothermally synthesized tungsten oxide nanowires/nanorods for $\mathrm{NO}_{2}$ gas sensor applications. J. Alloys Compd. 509, 8401-8406. doi: 10.1016/j.jallcom.2011.05.100

Qin, Y., Shen, W., Li, X., and Hu, M. (2011b). Effect of annealing on microstructure and $\mathrm{NO}_{2}$-sensing properties of tungsten oxide nanowires synthesized by solvothermal method. Sens. Actuat. B Chem. 155, 646-652. doi: 10.1016/j.snb.2011.01.024

Reich, S., Leitus, G., Popovitz-Biro, R., Goldbourt, A., and Vega, S. (2009). A Possible $2 \mathrm{D} \mathrm{H}_{\mathrm{X}} \mathrm{WO}_{3}$ Superconductor with a T c of $120 \mathrm{~K}$. J. Superconduct. Novel Magnet. 22, 343-346. doi: 10.1007/s10948-009-0443-3

Riley, R.S., and Day, E.S. (2017). Gold nanoparticle-mediated photothermal therapy: applications and opportunities for multimodal cancer treatment. Wiley Interdiscipl. Rev. Nanomed. Nanobiotechnol. 9:e1449. doi: 10.1002/wnan.1449

Rout, C.S., Hegde, M., and Rao, C.N.R. (2008). $\mathrm{H}_{2} \mathrm{~S}$ sensors based on tungsten oxide nanostructures. Sens. Actuat. B Chem. 128, 488-493. doi: $10.1016 /$ j.snb.2007.07.013

Schmidt, P., Binnewies, M., Glaum, R., and Schmidt, M. (2013). "Chemical vapor transport reactions-methods, materials, modeling," in Advanced Topics on Crystal Growth (London: InTech), 227-305.

Shang, M., Li, N., Zhang, S., Zhao, T., Zhang, C., Liu, C., et al. (2017). Full-spectrum solar-to-heat conversion membrane with interfacial plasmonic heating ability for high-efficiency desalination of seawater. ACS Appl. Energy Mater. 1, 56-61. doi: 10.1021/acsaem.7b00135

Son, K.H., Hong, J.H., and Lee, J.W. (2016). Carbon nanotubes as cancer therapeutic carriers and mediators. Int. J. Nanomed. 11, 5163-5185. doi: $10.2147 /$ IJN.S112660

Song, C., Li, T., Guo, W., Gao, Y., Yang, C., Zhang, Q., et al. (2018). Hydrophobic $\mathrm{Cu}_{12} \mathrm{Sb}_{4} \mathrm{~S}_{13}$-deposited photothermal film for interfacial water evaporation and thermal antibacterial activity. New J. Chem. 42, 3175-3179. doi: 10.1039/C7NJ04545J

Song, G., Han, L., Zou, W., Xiao, Z., Huang, X., Qin, Z., et al. (2014). A novel photothermal nanocrystals of $\mathrm{Cu}_{7} \mathrm{~S}_{4}$ hollow structure for efficient ablation of cancer cells. Nano Micro Lett. 6, 169-177. doi: 10.1007/BF03353781

Song, G., Wang, Q., Wang, Y., Lv, G., Li, C., Zou, R., et al. (2013). A low-toxic multifunctional nanoplatform based on $\mathrm{Cu}_{9} \mathrm{~S}_{5} @ \mathrm{mSiO}_{2}$ core-shell nanocomposites: combining photothermal- and chemotherapies with infrared thermal imaging for cancer treatment. Adv. Funct. Mater. 23, 4281-4292. doi: 10.1002/adfm.201203317

Song, K., Xiao, F., Zhang, L., Yue, F., Liang, X., Wang, J., et al. (2016). W ${ }_{18} \mathrm{O}_{49}$ nanowires grown on $\mathrm{g}_{-} \mathrm{C}_{3} \mathrm{~N}_{4}$ sheets with enhanced photocatalytic hydrogen evolution activity under visible light. J. Mol. Catal. A Chem. 418, 95-102. doi: 10.1016/j.molcata.2016.03.029

Stankova, M., Vilanova, X., Llobet, E., Calderer, J., Bittencourt, C., Pireaux, J., et al. (2005). Influence of the annealing and operating temperatures on the gassensing properties of $\mathrm{rf}$ sputtered $\mathrm{WO}_{3}$ thin-film sensors. Sens. Actuat. B Chem. 105, 271-277. doi: 10.1016/j.snb.2004.06.009

Su, C.-Y., and Lin, H.-C. (2009). Direct route to tungsten oxide nanorod bundles: microstructures and electro-optical properties. J. Phys. Chem. C 113, 40424046. doi: 10.1021/jp809458j

Sun, L., Li, Z., Su, R., Wang, Y., Li, Z., Du, B., et al. (2018). PhaseTransition induced conversion into a photothermal material: quasi-metallic $\mathrm{WO}_{2.9}$ Nanorods for solar water evaporation and anticancer photothermal therapy. Angew. Chem. Int. Ed. 57, 10666-10671. doi: 10.1002/anie.2018 06611

Sun, Y., Wang, W., Qin, J., Zhao, D., Mao, B., Xiao, Y., et al. (2016). Oxygen vacancy-rich mesoporous $\mathrm{W}_{18} \mathrm{O}_{49}$ nanobelts with ultrahigh initial Coulombic efficiency toward high-performance lithium storage. Electrochim. Acta 187, 329-339. doi: 10.1016/j.electacta.2015.11.064

Takeda, H., and Adachi, K. (2007). Near infrared absorption of tungsten oxide nanoparticle dispersions. J. Am. Ceram. Soc. 90, 4059-4061. doi: 10.1111/j.1551-2916.2007.02065.x
Tian, Q., Tang, M., Sun, Y., Zou, R., Chen, Z., Zhu, M., et al. (2011). Hydrophilic flower-like CuS superstructures as an efficient $980 \mathrm{~nm}$ laser-driven photothermal agent for ablation of cancer cells. Adv. Mater. 23, 3542-3547. doi: 10.1002/adma.2011 01295

Tian, Y., Cong, S., Su, W., Chen, H., Li, Q., Geng, F., et al. (2014). Synergy of $\mathrm{W}_{18} \mathrm{O}_{49}$ and polyaniline for smart supercapacitor electrode integrated with energy level indicating functionality. Nano Lett. 14, 2150-2156. doi: $10.1021 / \mathrm{nl} 5004448$

Vallejos, S., Gràcia, I., Bravo, J., Figueras, E., Hubálek, J., and Cané, C. (2015). Detection of volatile organic compounds using flexible gas sensing devices based on tungsten oxide nanostructures functionalized with $\mathrm{Au}$ and $\mathrm{Pt}$ nanoparticles. Talanta 139, 27-34. doi: 10.1016/j.talanta.2015.02.034

Venables, D.S., and Brown, M.E. (1996). Reduction of tungsten oxides with carbon. part 1: thermal analyses. Thermochim. Acta 282, 251-264. doi: 10.1016/0040-6031(95)02814-5

Wang, G., Ling, Y., Wang, H., Yang, X., Wang, C., Zhang, J.Z., et al. (2012). Hydrogen-treated $\mathrm{WO}_{3}$ nanoflakes show enhanced photostability. Energy Environ. Sci. 5, 6180-6187. doi: 10.1039/c2ee03158b

Wang, H.-Q., Hu, P.-F., Zheng, Y., Zhao, Z., Zheng, B., Chang, J., et al. (2017a). Construction of ICG encapsulated $\mathrm{W}_{18} \mathrm{O}_{49} @ \mathrm{MSN}$ as a fluorescence carrier for real-time tracked photothermal therapy. Mater. Sci. Eng. C 80, 102-109. doi: 10.1016/j.msec.2017.05.131

Wang, J., Li, Y., Deng, L., Wei, N., Weng, Y., Dong, S., et al. (2017b). High-performance photothermal conversion of narrow-bandgap $\mathrm{Ti}_{2} \mathrm{O}_{3}$ nanoparticles. Adv. Mater. 29:1603730. doi: 10.1002/adma.201603730

Wang, J., Liu, G., and Du, Y. (2003). Mechanochemical synthesis of sodium tungsten bronze nanocrystalline powders. Mater. Lett. 57, 3648-3652. doi: 10.1016/S0167-577X(03)00142-3

Wang, P. (2018). Emerging investigator series: the rise of nano-enabled photothermal materials for water evaporation and clean water production by sunlight. Environ. Sci. Nano 5, 1078-1089. doi: 10.1039/C8EN00156A

Wang, S., He, Y., Zou, J., Cao, P., Jiang, Y., Huang, B., et al. (2007). Synthesis of tungsten oxide tapered needles with nanotips. J. Cryst. Growth 303, 574-579. doi: $10.1016 /$ j.jcrysgro.2006.11.342

Wang, T., Hao, J., Zheng, S., Sun, Q., Zhang, D., and Wang, Y. (2018). Highly sensitive and rapidly responding room-temperature $\mathrm{NO}_{2}$ gas sensors based on $\mathrm{WO}_{3}$ nanorods/sulfonated graphene nanocomposites. Nano Res. 11, 791-803. doi: 10.1007/s12274-017-1688-y

Wang, X., Ou, G., Wang, N., and Wu, H. (2016a). Graphene-based recyclable photo-absorbers for high-efficiency seawater desalination. ACS Appl. Mater. Interfaces 8, 9194-9199. doi: 10.1021/acsami.6b02071

Wang, X., Wang, F., Sang, Y., and Liu, H. (2017c). Full-spectrum solar-lightactivated photocatalysts for light-chemical energy conversion. Adv. Energy Mater. 7:1700473. doi: 10.1002/aenm.201700473

Wang, Y., Zhang, L., and Wang, P. (2016b). Self-floating carbon nanotube membrane on macroporous silica substrate for highly efficient solar-driven interfacial water evaporation. ACS Sustain. Chem. Eng. 4, 1223-1230. doi: 10.1021/acssuschemeng.5b01274

Wang, Z., Ye, Q., Liang, X., Xu, J., Chang, C., Song, C., et al. (2017d). based membranes on silicone floaters for efficient and fast solar-driven interfacial evaporation under one sun. J. Mater. Chem. A 5, 16359-16368. doi: 10.1039/C7TA03262E

Wu, C.-M., Chou, M.-H., and Chala, T.F. (2017a). "Pyroelectricity of electrospun polyvinylidene fluoride/tungsten oxide nanofibrous membranes," in 22nd International Conference on Advanced Materials and Nanotechnology (Osaka, Japan).

Wu, X., Wang, J., Zhang, G., Katsumata, K.-I., Yanagisawa, K., Sato, T. et al. (2017b). Series of $\mathrm{M}_{\mathrm{X}} \mathrm{WO}_{3} / \mathrm{ZnO}(\mathrm{M}=\mathrm{K}, \mathrm{Rb}, \mathrm{NH} 4)$ nanocomposites: combination of energy saving and environmental decontamination functions. Appl. Catal. B Environ. 201, 128-136. doi: 10.1016/j.apcatb.2016.08.030

Wu, X., Yin, S., Xue, D., Komarneni, S., and Sato, T. (2015). A $\mathrm{Cs}_{\mathrm{X}} \mathrm{WO}_{3} / \mathrm{ZnO}$ nanocomposite as a smart coating for photocatalytic environmental cleanup and heat insulation. Nanoscale 7, 17048-17054. doi: 10.1039/C5NR04452A

Xi, G., Ouyang, S., Li, P., Ye, J., Ma, Q., Su, N., et al. (2012). Ultrathin $\mathrm{W}_{18} \mathrm{O}_{49}$ nanowires with diameters below $1 \mathrm{~nm}$ : synthesis, near-infrared absorption, photoluminescence, and photochemical reduction of carbon dioxide. Angew. Chem. 124, 2445-2449. doi: 10.1002/ange.201107681 
Xu, X.-Q., Wang, Z., Li, R., He, Y., and Wang, Y. (2018). A degradable and recyclable photothermal conversion polymer. Chem. A Eur. J. 24, 9769-9772. doi: 10.1002/chem.201801654

Yan, C., Tian, Q., and Yang, S. (2017). Recent advances in the rational design of copper chalcogenide to enhance the photothermal conversion efficiency for the photothermal ablation of cancer cells. RSC Adv. 7, 37887-37897. doi: 10.1039/C7RA05468H

Yan, J., Liu, P., Ma, C., Lin, Z., and Yang, G. (2016). Plasmonic near-touching titanium oxide nanoparticles to realize solar energy harvesting and effective local heating. Nanoscale 8, 8826-8838. doi: 10.1039/C6NR01295G

Yan, J., Wang, T., Wu, G., Dai, W., Guan, N., Li, L., et al. (2015). Tungsten oxide single crystal nanosheets for enhanced multichannel solar light harvesting. $A d v$. Mater. 27, 1580-1586. doi: 10.1002/adma.201404792

Yang, K., Zhang, S., Zhang, G., Sun, X., Lee, S.-T., and Liu, Z. (2010). Graphene in mice: ultrahigh in vivo tumor uptake and efficient photothermal therapy. Nano Lett. 10, 3318-3323. doi: 10.1021/nl100996u

Yang, X.-G., Li, C., Mo, M.-S., Zhan, J.-H., Yu, W.-C., Yan, Y., et al. (2003). Growth of $\mathrm{K}_{0.4} \mathrm{WO}_{3}$ whiskers via a pressure-relief-assisted hydrothermal process. J. Cryst. Growth 249, 594-599. doi: 10.1016/S0022-0248(02)02323-0

Yao, Y., Zhang, L., Chen, Z., Cao, C., Gao, Y., and Luo, H. (2018). Synthesis of $\mathrm{Cs}_{\mathrm{X}} \mathrm{WO}_{3}$ nanoparticles and their NIR shielding properties. Ceram. Int. 44, 13469-13475. doi: 10.1016/j.ceramint.2018.04.158

Yoon, S., Jo, C., Noh, S. Y., Lee, C. W., Song, J. H., and Lee, J. (2011a). Development of a high-performance anode for lithium ion batteries using novel ordered mesoporous tungsten oxide materials with high electrical conductivity. Phys. Chem. Chem. Phys. 13, 11060-11066. doi: 10.1039/c1cp20940j

Yoon, S., Kang, E., Kim, J. K., Lee, C. W., and Lee, J. (2011b). Development of high-performance supercapacitor electrodes using novel ordered mesoporous tungsten oxide materials with high electrical conductivity. Chem. Commun. 47, 1021-1023. doi: 10.1039/C0CC03594G

Yue, L., Tang, J., Li, F., Xu, N., Zhang, F., Zhang, Q., et al. (2017). Enhanced reversible lithium storage in ultrathin $\mathrm{W}_{18} \mathrm{O}_{49}$ nanowires entwined $\mathrm{Si}$ composite anode. Mater. Lett. 187, 118-122. doi: 10.1016/j.matlet.2016.10.093

Zeng, W., Suo, L., Zhang, C., Wu, D., and Zhu, H. (2019). AgI-Ag2S heterostructures for photothermal conversion and solar energy harvesting. J. Taiwan Inst. Chem. Eng. 95, 273-280. doi: 10.1016/j.jtice.2018.07.012

Zeng, X., Zhou, Y., Ji, S., Luo, H., Yao, H., Huang, X., et al. (2015). The preparation of a high performance near-infrared shielding $\mathrm{Cs}_{\mathrm{X}} \mathrm{WO}_{3} / \mathrm{SiO}_{2}$ composite resin coating and research on its optical stability under ultraviolet illumination. J. Mater. Chem. C 3, 8050-8060. doi: 10.1039/C5TC01411E

Zhang, L., Tang, B., Wu, J., Li, R., and Wang, P. (2015a). Hydrophobic light-to-heat conversion membranes with self-healing ability for interfacial solar heating. Adv. Mater.27, 4889-4894. doi: 10.1002/adma.201502362
Zhang, W., Yue, L., Zhang, F., Zhang, Q., Gui, X., Guan, R., et al. (2015b). Onestep in situ synthesis of ultrathin tungsten oxide@ carbon nanowire webs as an anode material for high performance. J. Mater. Chem. A 3, 6102-6109. doi: 10.1039/C4TA06262K

Zhang, Z., Jiang, X., Liu, B., Guo, L., Lu, N., Wang, L., et al. (2018). IRdriven ultrafast transfer of plasmonic hot electrons in non-metallic branched heterostructures for enhanced $\mathrm{H}_{2}$ generation. Adv. Mater. 30:1705221. doi: 10.1002/adma.201705221

Zhao, Y., Tang, Q., Yang, P., and He, B. (2017). Robust electrocatalysts from metal doped $\mathrm{W}_{18} \mathrm{O}_{49}$ nanofibers for hydrogen evolution. Chem. Commun. 53, 4323-4326. doi: 10.1039/C7CC01249G

Zheng, J.Y., Haider, Z., Van, T.K., Pawar, A.U., Kang, M.J., Kim, C.W., et al. (2015). Tuning of the crystal engineering and photoelectrochemical properties of crystalline tungsten oxide for optoelectronic device applications. CrystEngComm 17, 6070-6093. doi: 10.1039/C5CE0 0900F

Zhenzhen, G., Xin, M., Gang, W., Baofei, H., Xinghang, L., Tao, M., et al. (2018). Super-hydrophilic copper sulfide films as light absorbers for efficient solar steam generation under one sun illumination. Semicond. Sci. Technol. 33:025008. doi: 10.1088/1361-6641/aaa323

Zhou, M., Zhang, R., Huang, M., Lu, W., Song, S., Melancon, M.P., et al. (2010). A chelator-free multifunctional $[64 \mathrm{Cu}] \mathrm{CuS}$ nanoparticle platform for simultaneous micro-PET/CT Imaging and photothermal ablation therapy. J. Am. Chem. Soc. 132, 15351-15358. doi: 10.1021/ja106855m

Zhou, Y., Ko, S., Lee, C.W., Pyo, S.G., Kim, S.-K., and Yoon, S. (2013). Enhanced charge storage by optimization of pore structure in nanocomposite between ordered mesoporous carbon and nanosized $\mathrm{WO}_{3-\mathrm{x}}$. J. Pow. Sources 244 777-782. doi: 10.1016/j.jpowsour.2013.04.054

Zhu, Y.T., and Manthiram, A. (1994). New route for the synthesis of tungsten oxide bronzes. J. Solid State Chem. 110, 187-189. doi: 10.1006/jssc.1994. 1156

Conflict of Interest Statement: The authors declare that the research was conducted in the absence of any commercial or financial relationships that could be construed as a potential conflict of interest.

Copyright (c) 2019 Wu, Naseem, Chou, Wang and Jian. This is an open-access article distributed under the terms of the Creative Commons Attribution License (CC BY).

The use, distribution or reproduction in other forums is permitted, provided the original author(s) and the copyright owner(s) are credited and that the original publication in this journal is cited, in accordance with accepted academic practice. No use, distribution or reproduction is permitted which does not comply with these terms. 